\title{
Bireylerin Çalışma Düşüncesine Göre İşe Tutkunluk Düzeyindeki Farklılığın İncelenmesi

\author{
(Investigation of the Difference in the Work Engagement Level according to Individuals' \\ Thought of Work)
}

\author{
Mahmut ÖZDEMIR (iD a Ahmet DOĞAN (iD b \\ a Kırıkkale Üniversitesi, İşletme Bölümü, Kırıkkale, Türkiye. mahmudozdemir@hotmail.com \\ b Kırıkkale Üniversitesi, İşletme Bölümü, Kırıkkale, Türkiye. ahmet@ahmetdoganca.com
}

\begin{tabular}{|c|c|}
\hline MAK & ZET \\
\hline $\begin{array}{l}\text { Anahtar Kelimeler: } \\
\text { Çalışma Düşüncesi } \\
\text { İşe Tutkunluk } \\
\text { Dinçlik } \\
\text { Adanma } \\
\text { Yoğunlaşma }\end{array}$ & $\begin{array}{l}\text { Amaç - Bu çalışmanın temel amacı bireylerin işe tutkunluk düzeylerinin çalışma düşüncelerine göre } \\
\text { farklılaşıp farklılaşmadığını incelemektir. Ayrıca cinsiyet, yaş, deneyim, eğitim gibi demografik } \\
\text { niteliklere göre çalışma düşüncesinde farklılık olup olmadığının incelenmesi de bu çalışmanın ikincil } \\
\text { amacıdır. } \\
\text { Yöntem - Bu çalışmada Türkiye'de özel ve kamu sektöründe çalışan bireylerin işe tutkunluk düzeyleri ve } \\
\text { çalışma düşüncelerinin tespit edilmesi için kolayda örneklem yöntemi seçilmiştir. Veriler elektronik } \\
\text { ortamda anket aracılığıyla toplanmıştır. Araştırma amacına uygun olarak niceliksel verilerin analizinde } \\
\text { SPSS } 22.0 \text { programı kullanılmıştır. }\end{array}$ \\
\hline $\begin{array}{l}\text { Gönderilme Tarihi } 16 \text { Mart } \\
2021 \\
\text { Revizyon Tarihi } 3 \text { Temmuz } \\
2021 \\
\text { Kabul Tarihi } 10 \text { Temmuz }\end{array}$ & $\begin{array}{l}\text { Bulgular - Analiz sürecinde genel olarak çalışmayı lanet, meta ve ızdırap olarak değerlendiren bireylerin } \\
\text { işe tutkunluklarının çalışmayı özgürlük, kimlik ve hizmet olarak değerlendirenlere kıyasla istatistiki } \\
\text { olarak anlamlı bir biçimde daha düşük olduğu bulunmuştur. Ayrıca cinsiyet, öğrenim durumu, yaş, } \\
\text { deneyim süresi, çalışılan sektöre göre de çalışma düşüncesinde istatistiki olarak anlamlı farklılıklar tespit } \\
\text { edilmiştir. Ancak medeni durum, aylık kazanç ve pozisyona göre çalışma düşüncesinde istatistiki olarak } \\
\text { anlamlı farklılıklar olmadığı görülmüştür. }\end{array}$ \\
\hline $\begin{array}{l}\text { Mak } \\
\text { Arasst }\end{array}$ & $\begin{array}{l}\text { Tartışma - Bireylerin çalışma düşüncesi, oluşturdukları referans çerçeveleri değer ve tutumlar yoluyla } \\
\text { işlerine yönelik kavrayış ve uygulamalarını şekillendirmektedir. Bu araştırma sonuçları hem bireylerin } \\
\text { yaşam ve işe yönelik anlam ve değer verme, iş tatminini artırma gibi bireysel faydaların sağlanması hem } \\
\text { de örgütsel bağlılık ve motivasyon gibi örgütsel faydaların sağlanmasına katkı sunabilir niteliktedir. }\end{array}$ \\
\hline
\end{tabular}

\begin{tabular}{ll}
\hline ARTICLE INFO & ABSTRACT \\
\hline $\begin{array}{l}\text { Keywords: } \\
\text { Thought of Work }\end{array}$ & $\begin{array}{l}\text { Purpose - The main purpose of this study is to examine whether individuals' levels of work engagement } \\
\text { differ according to their thoughts of work. In addition, the secondary purpose of this study is to examine } \\
\text { Work Engagement } \\
\begin{array}{l}\text { Wigor } \\
\text { Dedication }\end{array} \\
\text { Design/methodology/approach - In this study, the convenience sampling method was selected to } \\
\text { determine the levels of work engagement and working thoughts of individuals working in the private } \\
\text { and public sectors in Turkey. Data were collected electronically through the questionnaire. In accordance } \\
\text { with the purpose of the research, SPSS 22.0 program was used in the analysis of quantitative data. }\end{array}$ \\
$\begin{array}{l}\text { Findings - In the analysis process, it was found that individuals who generally consider working as a } \\
\text { Received 16 March 2021 } \\
\text { curse, commodity, and suffering have significantly lower work engagement compared to those who }\end{array}$ \\
$\begin{array}{l}\text { Accepted 10 July 2021 } \\
\text { consider working as freedom, identity, and service. In addition, statistically significant differences were } \\
\text { found in the thought of work according to gender, education level, age, duration of experience, and the } \\
\text { Research Article }\end{array}$ \\
$\begin{array}{l}\text { sector employed. However, according to marital status, monthly earnings, and position, it was observed } \\
\text { that there were no statistically significant differences in the thought of work. } \\
\text { Discussion - The thought of work, the reference frames that individuals create shape their understanding } \\
\text { and practices towards their work through values and attitudes. At this point, the results of this study can } \\
\text { contribute to both provisions of individual benefits such as giving meaning and value to life and work, } \\
\text { increasing job satisfaction, and organizational benefits such as organizational commitment and } \\
\text { motivation. }\end{array}$
\end{tabular}




\section{GİRIŞ}

Yüzyıllar boyunca insan yaşamının ayrılmaz bir parçası olan çalışma bugün, bireyin tatmin duygusunu, haysiyetini ve refahını sürdürmek için bir gereklilik olarak görülmektedir (Nizami \& Prasad, 2017: xi). İnsanlık tarihi incelendiğinde çalışmanın yöntemi, biçimi, içeriği ve anlamının önemli ölçüde değiştiği görülmekte olup başta teknoloji olmak üzere toplumsal ve ekonomik yapılardaki hızlı değişimler göz önünde bulundurulduğunda çalışmanın yöntemi, biçimi, içeriği ve anlamı da değişmeye devam edecektir. Tüm bu değişimlerle birlikte bireylerin yaşamlarının temel ritmini belirleyen çalışma nedenleri ve çalışmaya yükledikleri anlamlar da farklılık göstermektedir. Her ne kadar bireylerin ve toplumların çalışmaya verdikleri anlam değişse bile Adler (2002: 33)'e göre insan hayatındaki bütün problemler bir şekilde sosyal yaşam, aşk ve çalışmaya ilişkin sorunlara bağlanabilir niteliktedir.

Ekonomi, sosyoloji, işletme, sosyal psikoloji, hukuk, siyaset bilimi, felsefe, teoloji gibi çok farklı disipline konu olan çalışma, ücretler, çalışma koşulları, üretimin içindeki yeri, teknolojik değişim, ekonomik ve sosyolojik etkileri, meslekler, kariyer, iş tatmini, liderlik, motivasyon, örgütsel bağlllık ve aidiyet, sendikalar ve sosyal güvenlik gibi pek çok farklı boyutta incelenmektedir.

Bireyler için çalışma her zaman bir anlama sahip olup, bireylerin çalışmaya verdikleri anlam ile anlamlı çalışma birbiriyle aynı şeyi ifade etmemektedir (Bailey \& Madden, 2019:2). Sosyoloji, psikoloji ve felsefe alanındaki araştırmacılar, anlamlılık ve anlam verme deneyiminin temel bir insan ihtiyacı ve sağlıklı psikolojik işleyişin bir işareti olduğunu öne sürmektedir (Bailey \& Madden, 2015: 2). Bu araştırmada öncelikle bireylerin gündelik yaşantısında Budd (2011:41) tarafından yapılan tasniflemeye uygun olarak çalışmayı nasıl kavramlaştırdıkları, çalışmanın bireyler için ne anlam ifade ettiği incelenecektir. Daha sonra ise bireylerin çalışma konusundaki bu değerlendirmelerinin işe tutkunluk düzeylerinde farklılı̆ga neden olup olmadığ 1 tespit edilmeye çalışılacaktır.

Çalışma ve örgütsel davranışlarla ile ilgili yapılan araştırmalar incelendiğinde iş performansı, kurumsal aidiyet, örgütsel bağlılık gibi örgütsel davranışların birbirleriyle ilişkisi, sonuç ya öncüllerinin belirlenmesine yönelik pek çok araştırmanın olduğu görülmektedir. Ayrıca kısa vadeli örgütsel zorunluklardan memnuniyetsizlik, iş kalitesiyle ilgili artan endişeler ve bireylerin anlam ve amaç bulmak için odaklandıkları bir alan olarak çalışmaya odaklanmaları nedeniyle son dönemlerde hem araştırmacılar hem de uygulayıcılar arasında anlamlı çalışma konusunda araştırmalar yaygın hale gelmiştir (Bailey, Yeoman, Madden, Thompson, \& Kerridge, 2018: 2). Ancak yapılan alan taramasında Budd tarafından yapılan kavramlaştırma çerçevesinde bireylerin çalışma düşüncelerinin örgütsel davranışlarla ilişkisini inceleyen araştırmaya rastlanılamamıştır.

$\mathrm{Bu}$ araştırmaya benzer nitelikte çalı̧̧ma düşüncesi ile örgütsel davranışlar arasındaki ilişkileri inceleyen çalışmaların artması alan yazınının gelişimine katkı sağlayacaktır. Bununla birlikte çalışma düşüncesi ve örgütsel davranışlar arasındaki ilişkileri inceleyen araştırmaların sonuçları başta insan kaynakları yönetimi uygulayıcıları olmak üzere yöneticilere çalı̧anların pozitif örgütsel davranış sergilemeleri amacıyla geliştirecekleri çalışmalar için farklı bakış açıları kazandıracaktır.

\section{Kavramsal Çerçeve}

\section{1. Çalışma Düşüncesi}

Çalışmanın tarihsel süreçte en aşağı ve hakir görülen konumdan, bütün insani etkinlikler arasında en itibarlı ve en yüksek mertebeye yükseldiğini belirten Arendt (1994: 160), bu yükselişin Locke'un her türlü mülkiyetin kaynağının emek olduğunu keşfetmesiyle başladığı, ardından Smith'in her türlü zenginliğin kaynağının emek olduğunu ileri sürmesiyle pekiştiği ve nihayetinde Marx'ın emek sistemi ile rayına oturduğunu belirtir.

Aristoteles (2018: 163-164)'e göre köle ve hür kişilerden oluşan tam teşekküllü bir hane içinde kölenin rolü diğer araçları çalıştırmak için ihtiyaç duyulan yardımcı niteliği ile eylemek için bir araçtır. Bu bağlamda çalışma hür kişilere değil kölelere ait bir rol olarak tanımlanmaktadır. Buna karşın insanın diğer bütün mülkiyet haklarının temelinde kendi emeği üzerindeki tasarrufunun olduğunu ifade eden Smith (2011:135), emek üzerindeki mülkiyet hakkının en kutsal ve en dokunulmazı olduğunu, komşusuna zararı dokunmadıkça insanların emeklerini en uygun gördüğü biçimde kullanabileceğini, bundan alıkonmasının ise 


\section{M. Özdemir - A. Doğan 13/3 (2021) 2203-2222}

kanuni özgürlüğün çiğnenmesi olduğunu ifade eder. Smith'e göre çalışma özgürlüğü herkesi günlük zorlukların cenderesinden kurtarabilir özel bir niteliğe sahiptir (Skousen, 2003:19).

Çalışmaya yönelik tutumların değişiminde, üretim teknolojileri ve modellerinin değişiminin büyük bir önemi vardır. Bu noktada en ayırdedici özelliklerinden birisinin son derece karmaşık olan işbölümünün olduğu modern toplumlarda çalışma, insanların uzmanlaştığı çok fazla sayıda mesleklere bölünmüş bulunmaktadır. Sanayileşmeden önce, büyük bir bölümü evde ve evhalkı ile birlikte gerçekleşen çalışmanın, bireylerin yaşamlarındaki etki ve önemi sanayi teknolojisindeki ilerlemeler nedeniyle büyük ölçüde değişmiştir. Örneğin bireylerin ev ve iş yeri birbirinden ayrılmıştır (Giddens, 2012: 794). Bu değişimler aile biçimleri, ev içi roller gibi pek çok toplumsal ve ekonomik faktörden etkilenmiş ve söz konusu faktörleri de etkilemiştir. Buradan hareket eden Prost (2010: 21) yirminci yüzyılda yaşanan ilk büyük evriminin emeğin bütünüyle özel alandan çıkarak kamusal alana girmesi olduğunu savunmuştur.

Sadece ücretli çalışmanın değerli iş olduğunun kabul edildiği bu dönemde evlerdeki ücretsiz bakım işleri görünmez hale gelmiş, işyerlerindeki işçileri yönetmek, denetlemek ve motive etmek için yeni meslekler ortaya çımıştır (Budd, 2011: 29).

Yirmi birinci yüzyılda teknolojik dinamizm, artan iletişim dereceleri ve neredeyse mükemmele yakın bilginin verdiği ivme ile çalışmanın tanımı, yirminci yüzyılda işgücü piyasasının tanımlanmış geleneksel çizgileri kırılarak yeniden yapılmaya çalışılmaktadır (Nizami \& Prasad, 2017: ix). Endüstriyel ve kitlesel üretimin olduğu kurumlarda ve dönemlerde herkesin birlikte çalışması bir gereklilikken, bilgi ekonomisi bağlamında çalışmanın aynı ortamda birlikte iş görme ve işyerinde harcanan zaman ile ölçülemeyecek bir boyut ve nitelik kazandığı görülmektedir (Nizami \& Prasad, 2017: 5).

Bireyler açısından ihmal edilemeyecek kadar önemli olan çalışmanın değerinin günümüz düşünürleri, politikacıları, liderleri tarafından büyük ölçüde bir gereklilik ya da gelir kazanma aracı olarak görülerek aşırı derecede basitleştirildiğini ve gözden kaçırıldığını ifade eden Budd (2011: 40) çalışmayı Tablo 1'de görüldügü üzere 10 farklı biçimde kavramsallaştırmıştır.

Tablo 1. Çalışma Düşüncesinin Kavramsallaştırılması

\begin{tabular}{|c|c|c|}
\hline ...Olarak Çalışma & Tanım & Entelektüel Temeller \\
\hline Bir Lanet & $\begin{array}{l}\text { Çalışma katlanılması gereken bir yük / } \\
\text { zorunluluktur. İnsan yaşamı ya da sosyal } \\
\text { düzenin devamı için gerekli olan kesin bir } \\
\text { yüktür. }\end{array}$ & $\begin{array}{l}\text { Batı ilahiyatı, Antik Yunan- } \\
\text { Roma Felsefesi }\end{array}$ \\
\hline Özgürlük & $\begin{array}{l}\text { Doğadan ya da başka insanlardan bağımsız } \\
\text { olma durumuna erişmenin ve insan } \\
\text { yaratıcllğ̆ının ifadesinin bir yoludur. }\end{array}$ & $\begin{array}{l}\text { Batı liberal bireyciliği, Siyaset } \\
\text { teorisi }\end{array}$ \\
\hline Bir Meta & $\begin{array}{l}\text { İnsanın para kazanma aracıdır. Satılabilir } \\
\text { ekonomik değere sahip olan üretken çabanın } \\
\text { soyut bir miktarıdır. }\end{array}$ & Kapitalizm, Sanayileşme, İktisat \\
\hline Mesleki Vatandaşlık & $\begin{array}{l}\text { Belirli hakları olan bir toplumun mensupları } \\
\text { tarafından takip edilen bir aktivitedir. }\end{array}$ & $\begin{array}{l}\text { Batı vatandaşlık idealleri, } \\
\text { İlahiyat, Endüstri ilişkileri }\end{array}$ \\
\hline Izdirap & $\begin{array}{l}\text { Başka faydaları edinmek için katlanmak } \\
\text { zorunda olunan maliyet. Memnuniyet veren mal } \\
\text { ve hizmetlerin elde edilmesine imkan veren } \\
\text { berbat bir aktivitedir. }\end{array}$ & Faydacılık, İktisat \\
\hline Kişisel Tatmin & $\begin{array}{l}\text { Tercihen bireysel ihtiyaçları tatmin eden fiziksel } \\
\text { ve psikolojik bir işleyiştir. }\end{array}$ & $\begin{array}{l}\text { Batı liberal bireyciliği, Sistematik } \\
\text { yönetim, Psikoloji }\end{array}$ \\
\hline Bir Sosyal İlişki & $\begin{array}{l}\text { Sosyal normlar, kurumlar ve iktidar yapıları } \\
\text { içine gömülü olan insan etkileşimidir. }\end{array}$ & $\begin{array}{l}\text { Sanayileşme, } \\
\text { Antropoloji }\end{array}$ \\
\hline Başkalarına Bakma & $\begin{array}{l}\text { Başkalarıyla birlikte olmak ve onların hayatta } \\
\text { kalmalarını sağlamak için gerekli olan fiziksel } \\
\text { bilişsel ve duygusal çabadır. }\end{array}$ & Kadın hakları, Feminizm \\
\hline
\end{tabular}




\begin{tabular}{lll}
\hline Kimlik & $\begin{array}{l}\text { Kim olduğunu ve sosyal yapı içinde nerede } \\
\text { durduğunu anlamaya yönelik bir metot. }\end{array}$ & Psikoloji, Sosyoloji, Felsefe \\
\hline Hizmet & $\begin{array}{l}\text { Başkalarına (Yaratıcıya, ülkeye, bir gruba vb.) } \\
\text { hizmet etmenin aracıdır. Başkalarına yönelik } \\
\text { fedakarlık çabasıdır. }\end{array}$ & $\begin{array}{l}\text { Cumhuriyetçilik, İnsançülllı } \\
\end{array}$ \\
\hline
\end{tabular}

Kaynak (Budd 2011: 41-42)

\section{2. İșe Tutkunluk}

İngilizce literatürde "work engagement" olarak ifade edilen kavramın Türkçe karşılığı incelendiğinde, çalışmaya tutkunluk (Turgut, 2010: 57), işe angaje olma (Özkalp ve Meydan, 2015:4), işle bütünleşme (Ardıç ve Polatçı, 2009: 21), iş bütünleşmesi (Demirbaş, 2008: 27) gibi farklı biçimlerde kullanıldığ1 görülmektedir. Kavramın pek çok araştırmacı tarafından farklı şekilde yapılması, konuyla ilgilenen bireylerin söz konusu çalışmaları takip etmesini zorlaştırmakta ve konunun bütünsel olarak incelenmesinde önemli sorunlara yol açmaktadır.

İşe tutkunluk, Türkçe karşıllğı konusundaki bu zorluklara rağmen son dönemlerde hem bilim insanları hem de uygulayıcılar tarafından iyi bilenen ve oldukça popüler bir kavram olarak karşımıza çıkmaktadır. Özellikle ikinci dünya savaşının ardından psikoloji bilimindeki pozitife odaklanma yönelimi örgüt psikolojisine de yansımıştır (Riggio, 2013: 5). Örgüt psikolojindeki olumluya odaklanmanın yansımalarından biri olan işe tutkunluk, 'canlılık, adanma ve yoğunlaşma ile karakterize edilen pozitif, tatmin edici, işle ilgili ruh hali' (Schaufeli, Salanova, Gonzalez-Roma, \& Bakker, 2002: 74) şeklinde tanımlanabilir.

Teorik alt yapısı Goffman'ın çalışmalarından hareket eden Kahn (1990:692) tarafından oluşturulan işe tutkunluk ile ilgili tanımlar incelendiğinde, söz konusu tanımlamaların bireylerin işle ilgili performanslarına ve görevlerine yüksek düzeyde kişisel yatırımları çerçevesinde yoğunlaştı̆̆ı (Kahn, 1990:694; Schaufeli \& Bakker, 2004: 295; Salanova, Agut, \& Peiro, 2005:1218; Saks, 2006: 602; Macey \& Schneider, 2008:3; Imperatori, 2017: 1) görülmektedir.

İşe tutkunluğun bileşen ya da boyutları incelendiğinde ise farklı araştırmacılar tarafından farklı sınıflandırmalar yapıldığı görülmektedir. Örneğin Kahn'a göre işe tutkunluk, bilişsel, fiziksel ve duygusal (1990: 694) bileşenlerden oluşurken, Rothbard'a göre dikkat ve yoğunlaşma bileşenlerinden oluşur (2001: 656).

İşe tutkunluğun boyutları ile yapılan farklı sınıflamalar olmakla birlikte Schaufeli, Bakker, \& Salanova tarafından, UWES ölçeğinin 17 maddelik ve kısaltılmış 9 maddelik iki farklı versiyonunun uygulandığı 10 farklı ülkeyi kapsayan çalışmalarında işe tutkunluğun dinçlik, yoğunlaşma ve adanma olmak üzere üç faktörlü yapısının istatistiki olarak daha fazla uyum iyiliği gösterdiği ifade edilmiştir (2006:712).

Dinçlik: Bireylerin işlerinde kendileriyle ilgili olarak deneyimledikleri fiziksel güç, duygusal enerji ve bilişsel canlılık düzeylerini ifade eder (Shirom, 2010: 69). Çalışanların işlerinde enerji ve zihinsel dayanaklılığı ile işlerinde yüksek verimle çalışma konusunda istekliliği şeklinde tanımlanabilir (Mauno, Kinnunen, Mäkikangas, \& Feldt, 2010:111).

Adanma: Çalışmaya ilişkin olarak anlam, coşku, ilham, gurur ve mücadele etme duygularıyla karakterize edilen adanma (Schaufeli, Salanova, Gonzalez-Roma, \& Bakker, 2002: 74 ), bireyin çalışmasıyla güçlü bir şekilde özdeşleşmesiyle yakından ilgilidir (Mauno, Kinnunen, Mäkikangas, \& Feldt, 2010:111).

Yoğunlaşma: Bireyin işine tamamen konsantre olması ve derinlemesine dalması ile karakterize edilir. Csikszentmihalyi tarafından tanımlanan akış kavramına benzer şekilde yoğunlaşma yaşayan birey için işte zaman hızla geçer ve kişi kendini işten ayırmakta güçlük çeker (Schaufeli, Salanova, Gonzalez-Roma, \& Bakker, 2002: 7).

İşe tutkunluğun kazanımlarını bireylere yönelik kazanımları, bireyler ve kuruma yönelik kazanımları ve sadece kurumlara yönelik kazanımları açısından tasnif etmek mümkündür. Bu tasnife göre,

- Bireylere yönelik kazanımları: Esenlik ve iş tatmininin artması

- Birey ve kurumlara yönelik kazanımları: Kişisel inisiyatif ve yüksek performans gösterme 
- Kurumlara yönelik kazanımları: Kuruma bağlılık, örgütsel vatandaşlık davranışlarının artması ve işten ayrılma niyetinin düşmesi olarak ifade edilebilir (Turgut, 2010: 80-83).

Tüm coğrafyalarda çalışanların işe tutkunlukları işin geleceği, bireylerin nasıl ve nerede çalıştıkları, işten ne bekledikleri ve işte onlardan ne beklenildiği ile ilgili (Turner, 2020: 5) olup, iş ilişkileri, bireylerin performanslarıyla ilgili bilişsel, duygusal ve davranışsal bileşenlere ilave olarak işlerinde ve örgütteki özkendilik deneyimlerini içerir (Imperatori, 2017: 2).

\section{YÖNTEM}

\subsection{Araştırma Modeli}

Çalışma kapsamında nicel araştırma yöntemi kullanılmıştır. Bireylerin çalışma düşüncesine göre işe tutkunluk düzeylerindeki farklılığı saptamaya yönelik oluşturulan model Şekil 2'de gösterilmektedir.

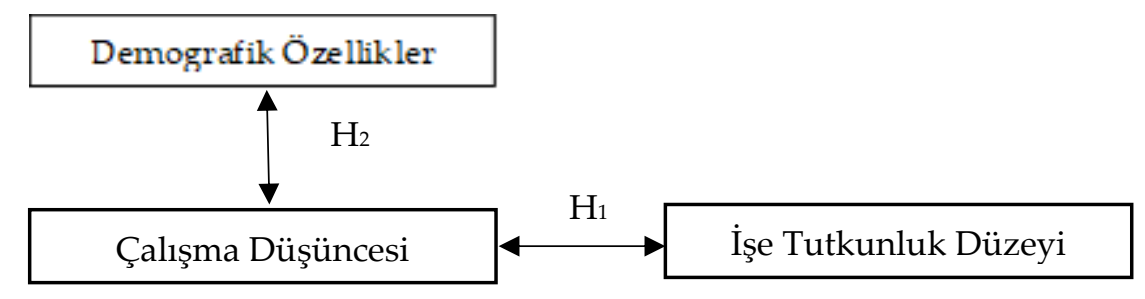

Şekil 1. Bireylerin Çalışma Düşüncesine Göre İşe Tutkunluk Düzeyindeki Farklılıkları Araştırma Modeli

\subsection{Araştırmanın Hipotezleri}

Bireylerin diğer bireyler, nesneler ya düşüncelerle ilgili değerlendirmeleri olarak tanımlanabilen tutumlar, gözlenebilen davranışlar olmamakla birlikte davranışa hazırlayıcı eğilimlerdir (Aronson, Wilson, \& Akert, 2012:357-359). Bu noktada davranışlar gözlenebilir ve bireylerin tutumlarına atfedilirler. Davranışları açıklamak için tutumlar tek başına yeterli olmayıp, tutum ve davranış arasındaki ilişki pek çok faktörden etkilenebilmektedir. Ancak yine de tutum ile davranış arasındaki ilişki şekil 1 'de görüldügü üzere basit bir biçimde ifade edilebilir (Kağıtçıbaşı, 1999: 102).

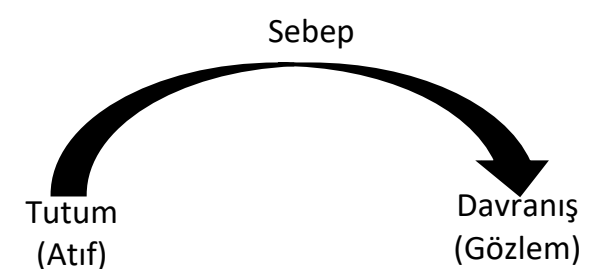

Şekil 2. Tutum - Davranış İlişkisi

Buna göre bireylerin çalışmaya ilişkin düşünce ve tutumlarının işe tutkunluk başta olmak üzere pek çok örgütsel davranış üzerinde etkili olması beklenmektedir. Bu çalışmanın temel amacı bireylerin çalışma düşüncelerine yani çalışmaya yönelik atıflarına göre işe tutkunluk düzeylerinde farklılık olup olmadığını belirlemek olup, bireylerin demografik özelliklerine göre çalışmaya bakışlarında farklılık olup olmadığının da belirlenmesi bu çalışmanın amaçları arasında yer almaktadır. Amaçlardan yola çıkılarak aşağıdaki hipotezler kurulmuştur.

H1: Bireylerin çalışma düşüncesine göre işe tutkunluk düzeylerinde farklılık vardır.

$\mathrm{H}_{1 a}$ : Bireylerin çalışma düşüncesine göre adanma düzeylerinde farklılık vardır.

Hıb: Bireylerin çalışma düşüncesine göre dinçlik düzeylerinde farklılık vardır.

Hıc: Bireylerin çalışma düşüncesine göre yoğunlaşma düzeylerinde farklılık vardır.

$\mathrm{H}_{2}$ : Demografik özelliklere göre çalışma düşüncesinde farklılık vardır.

$\mathrm{H}_{2 a}$ : Cinsiyete göre çalışma düşüncesinde farklılık vardır.

$\mathrm{H}_{2 b}$ : Medeni duruma göre çalışma düşüncesinde farklılık vardır.

$\mathrm{H}_{2 c}$ : Eğitim durumuna göre çalışma düşüncesinde farklılık vardır.

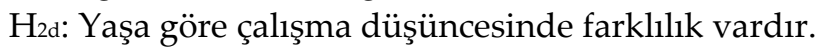


$\mathrm{H}_{22}$ : Çalışılan pozisyona göre çalışma düşüncesinde farklılık vardır.

$\mathrm{H}_{2 f:}$ Çalışılan sektöre göre çalışma düşüncesinde farklılık vardır.

$\mathrm{H}_{2 g}$ : Çalışma süresine göre çalışma düşüncesinde farklılık vardır.

\subsection{Yöntem ve Kapsamı}

Araştırma modelinde belirtildiği üzere, bireylerin çalışma düşüncelerine göre işe tutkunluk düzeylerinde farklılığın olup olmadığının incelenmesi amacıyla, betimsel model türlerinden tarama yöntemi seçilmiştir. Araştırmanın uygulanabilmesi için işe tutkunluk ölçeği (UWES17), çalışma düşünceleri ve demografik özelliklere ilişkin sorulardan oluşan anket ölçme aracı olarak kullanılmıştır. Araştırmayla ilgili olarak etik kurul izni Kırıkkale Üniversitesi Sosyal ve Beşeri Bilimler Araştırmaları Etik Kurulunun 08.02.2021 tarih ve 25 sayılı kararıyla alınmıştır.

Çalışma düşüncesinin tespitinde Budd (2011:14-48) tarafından bireyler için çalışmanın ne anlama geldiği ve toplumun ona ne değer verdiği hususunda temel sağlamak üzere yapılan literatür taraması ve tarihsel inceleme sonucunda geliştirilen on kavram esas alınmıştır.

Araştırmanın evrenini Türkiye'de kamu ve özel sektörde çalışan bireyler oluşturmaktadır. TÜíK verilerine göre Eylül 2020 itibariyle 27.707.000 kişi istihdam edilmektedir. Ancak bu rakama, kendi nam ve hesabına çalışanlar, işverenler, ücretsiz aile işçileri de dâhildir. Söz konusu dönemde bu araştırmanın evrenini oluşturan ücretli ya da yevmiyeli çalışan kişi sayısının 19.209.000 olduğu Eylül 2020 işgücü istatistiklerinde belirtilmiştir (TÜIK, 2021).

Araştırma kapsamında verilerin toplanması için elektronik ortamda ve kolayda örnekleme yöntemi tercih edilmiştir. \%95 güvenilirlik seviyesi ve evrenin homojen olmadığı kabulü ile gerekli olan örneklem sayısı 384 olarak hesaplanmıştır (Saruhan \& Özdemirci, 2016: 200). Buna göre araştırmaya dahil olan 584 katılımcı ile gerekli örneklem sayısına ulaşılmıştır.

Araştırma kapsamında elde edilen verilerin analizinde betimleyici istatistikler, geçerlilik ve güvenilirlik analizleri, ANOVA, Ki-Kare ve T-testleri SPSS 22 programı aracılı̆̆ıyla yapılmıştır.

\subsection{Araştırmada Kullanılan Ölçeğin Güvenilirlik ve Geçerlilik Analizi}

Araştırmada çalışanların işe tutkunluk düzeylerinin ölçülmesi için UWES 17 (Schaufeli \& Bakker, 2004) ölçeği kullanılmıştır. Ölçeğin Türkçe uyarlamasına ilişkin geçerlilik ve güvenilirlik analizi Eryılmaz ve Doğan (2012) tarafından yapılmıştır. Araştırmacılar tarafından ölçeğin iç faktörü yapısının Türk örneklemde de korunduğu, Cronbach alfa güvenirlik katsayısının ,94 olarak bulunduğu ifade edilmiştir (Eryılmaz \& Doğan, 2012: 33).

İşe tutkunluk ölçeğinin güvenilirlik ve geçerlilik testlerini yapmadan önce normal dağılım ön koşulunu sağlayıp sağlamadıkları incelenmiştir. Ölçekte yer alan 11. Madde haricindeki tüm maddelerin basıklık (kurtosis) ve çarpıklık (skewness) katsayılarının -2 ile +2 değeri arasında olduğu görülmüştür. George ve Mallery (2016: 114)'e göre çarpıklık ve basıklık değerlerinin -2 ile +2 aralığında olması verilerin normal dağılım gösterdiğini belirtmektedir. İşe tutkunluk ölçeğindeki 11. Madde normal dağılım ön koşulunu sağlamadığından analizin dışında tutulmuştur. Analizin ilerleyen aşamalarında işe tutkunluk ölçeğindeki 17. Maddenin iki faktörde birbirine yakın faktör ağırlığı olduğu görüldüğ̈̈nden analizin dışında tutulmuştur. Bu açılamalar doğrultusunda ölçeğin güvenilirlik ve geçerlilik analizleri yapılmıştır.

İşe tutkunluk ölçeğinin yapı geçerliliğini test etmek için açımlayıcı faktör analizi uygulanmıştır. Verilerin analize uygunluğuna ilişkin Kaiser-Meyer-Olkin (KMO) Örneklem Yeterliliği ve Barlett's Küresellik Test değerleri Tablo 2'de görülmektedir. Buna göre KMO değeri ,944 ve Barlett's Küresellik Test değeri $(, 000)$ incelendiğinde verilerin faktör analizine uygun olduğu görülmüsstür (George \& Mallery, 2016: 264).

Tablo 2. KMO ve Bartlett's Testi

\begin{tabular}{llr}
\hline Kaiser-Meyer-Olkin (KMO) Örneklem Yeterliliği &, 944 \\
\hline Barlett's Küresellik Test & Ki-Kare & 5458,841 \\
\cline { 2 - 3 } & Sd. & 105 \\
\cline { 2 - 3 } & P &, 000 \\
\hline
\end{tabular}


Tablo 3'te işe tutkunluk ölçeğinin açımlayıcı faktör analizinin toplam açıklanan varyansı ve faktörlerin özdeğerlerine ilişkin istatistikler görülmektedir.

Tablo 3. İşe Tutkunluk Ölçeğinin Toplam Açıklanan Varyans Tablosu

\begin{tabular}{lccc}
\hline & Özdeğer & Açıklanan Varyans (\%) & Kümülatif Varyans (\%) \\
\hline Faktör 1 & 4,424 & 29,494 & 29,494 \\
\hline Faktör 2 & 3,998 & 26,651 & 56,145 \\
\hline Faktör 3 & 1,654 & 11,024 & 67,169 \\
\hline
\end{tabular}

Faktör analizi yapılırken minimum örnekleme yeterliliği 0,5 olarak belirlenmiş ve rotation seçeneği olarak varimax yöntemi seçilmiştir. Ölçeğin faktör yapısı ve ifadelerin faktör yeterlilikleri Tablo 4'te görülmektedir.

Tablo 4. İşe Tutkunluk Ölçeği Faktör Analiz Sonuçları

\begin{tabular}{|c|c|c|c|}
\hline & \multicolumn{3}{|c|}{ Faktör Yükleri } \\
\hline & 1 (Dinçlik) & 2 (Adanma) & 3 (Yoğunlaşma) \\
\hline İşim bana ilham verir. & 816 & & \\
\hline İşimde kendimi güçlü ve dinç hissederim. & 802 & & \\
\hline Sabah uyandığımda işe gitmek için istekli olurum. & ,789 & & \\
\hline İşimi hevesle yaparım. & ,713 & & \\
\hline Yaptığım işle gurur duyarım. & 698 & & \\
\hline İşimin ilgi çekici ve gayret gerektiren bir iş olduğunu düşünüyorum. & 697 & & \\
\hline Çalışırken yaptığım işe kendimi kaptırırım. & & 833 & \\
\hline Çalışırken işime dalıp giderim. & & 832 & \\
\hline İşimde zihinsel olarak oldukça dayanıklıyım. & & 718 & \\
\hline Çalışırken zamanın nasıl geçtiğini anlamam. & & ,705 & \\
\hline Her şey yolunda gitmese bile işimde daima sebat ederim. & & ,597 & \\
\hline Çalışırken işim dışında hiçbir şeyi düşünmem. & &, 577 & \\
\hline Çalışırken mola vermekte zorlanırım. & & & 828 \\
\hline Çok uzun saatler çalışabilirim. & & & , 550 \\
\hline Yoğun çalıştığım zamanlarda kendimi mutlu hissederim. & & & 526 \\
\hline
\end{tabular}

Tablo 4'te görülen faktör analiz sonuçları işe tutkunluk ölçeğinin orijinal yapısı ile kıyaslandığında bu çalışmada da ölçeğin üç faktörlü yapısını koruduğu görülmekle birlikte, ölçek içindeki maddelerin faktörler içinde farklı şekilde dağıldığı görülmektedir. Örneğin bu araştırmada bulunan ve üç maddeden oluşan üçüncü faktördeki iki önerme (Çalışırken mola vermekte zorlanırım, Yoğun çalıştığım zamanlarda kendimi mutlu hissederim.) yoğunlaşma faktörünün, bir önerme ise (Çok uzun saatler çalışabilirim) dinçlik faktörünün içerisinde yer almaktadır. Her ne kadar bu çalışmadaki analizde ölçeğin orijinal yapısıyla birebir uygun yapısı elde edilememiş olsa da yeni faktör yapısında ölçeğin orijinal faktör isimleri kullanılmıştır. Buna göre 1. Faktör "Dinçlik", 2. Faktör "Adanma" ve 3. Faktör "Yoğunlaşma" olarak isimlendirilmiştir.

Ölçeğin geneli ve yeni faktör yapısına ilişkin güvenirlik analizi sonuçları Tablo 5 'te yer almaktadır. Cronbach's Alfa değerleri incelendiğinde, ölçek geneli, dinçlik ve adanma faktörünün "iyi", yoğunlaşma faktörünün ise “orta” derece güvenilirlik düzeyinde olduğu görülmektedir (Saruhan \& Özdemirci, 2016: 196).

Tablo 5. Güvenilirlik Analiz Sonuçları

\begin{tabular}{lcc}
\hline & Cronbach's Alpha & Madde Sayısı \\
\hline İşe Tutkunluk Ölçek Geneli & 0,924 & 15 \\
\hline Dinçlik & 0,92 & 6 \\
\hline Adanma & 0,874 & 6 \\
\hline Yoğunlaşma & 0,615 & 3 \\
\hline
\end{tabular}




\section{BULGULAR}

Araştırma katılımcılarına ilişkin demografik bilgiler Tablo 6'da yer almaktadır. Buna göre Tablo 6 incelendiğinde, katılımcıların \%41,3 'ünün erkek, \%58,7'sinin kadın olduğu, \% 30,7'sinin bekar \%69,3'ünün ise evli olduğu görülmektedir.

Katılımcıların yaş grupları incelendiğinde ise \%28,8'inin 18-34 yaş aralığında, \%38,9'unun 35-44 yaş aralığında \%32,4'ünün ise 45 yaş ve üzerinde olduğu tespit edilmiştir. Katılımclların \%52,1'i kamu kurumlarında \%47,9'u ise özel sektör veya STK'larda çalışmaktadır.

2020 yılı AGİ hariç asgari ücret düzeyi baz alındığında, katılımcıların aylık ortalama ücret gelirleri incelendiğinde, \%33,2'sinin bir asgari ücret ile iki asgari ücret arasında ( 2 asgari ücretten az), \%43,3'ünün 2 asgari ücretle 3 asgari ücret arasında ( 3 asgari ücretten az) ve \% 23,5'inin ise üç asgari ücret veya daha fazla ücret gelirine sahip olduğu görülmektedir.

Katılımcıların \%18,8'i yönetsel olmayan emek yoğun işlerde, \%47,8'i yönetsel olmayan bilgi yoğun işlerde ve 33,4'ü yönetsel pozisyonlarda çalışmaktadır.

Tablo 6. Katılımcıların Demografik Özelliklere Göre Dağılımı

\begin{tabular}{|c|c|c|}
\hline \multicolumn{3}{|c|}{ Cinsiyet } \\
\hline & $\mathrm{f}$ & $\%$ \\
\hline Erkek & 241 & 41,3 \\
\hline Kadın & 343 & 58,7 \\
\hline Toplam & 584 & 100 \\
\hline \multicolumn{3}{|c|}{ Medeni Durum } \\
\hline Bekar & 179 & 30,7 \\
\hline Evli & 405 & 69,3 \\
\hline Toplam & 584 & 100 \\
\hline \multicolumn{3}{|c|}{ Yaş Grup } \\
\hline 18-34 Yas & 168 & 28,8 \\
\hline 35-44 Yas & 227 & 38,9 \\
\hline 45 Yaş ve üzeri & 189 & 32,4 \\
\hline Toplam & 584 & 100 \\
\hline \multicolumn{3}{|c|}{ Çalışılan Sektör } \\
\hline Kamu & 304 & 52,1 \\
\hline Özel /STK & 280 & 47,9 \\
\hline Toplam & 584 & 100 \\
\hline \multicolumn{3}{|c|}{ Öğrenim Grup } \\
\hline Ön Lisans ve Altı & 147 & 25,2 \\
\hline Lisans & 309 & 52,9 \\
\hline Lisans Üstü & 128 & 21,9 \\
\hline Toplam & 584 & 100 \\
\hline \multicolumn{3}{|c|}{ Çalışma Süresi } \\
\hline 1-9 Y1l & 180 & 30,8 \\
\hline 10-19 Y1l & 178 & 30,5 \\
\hline 20 Yıl ve üzeri & 226 & 38,7 \\
\hline Toplam & 584 & 100 \\
\hline \multicolumn{3}{|c|}{ Ücret Grup } \\
\hline 0-4649 (1 - 2 Asgari Ücret Arası) & 194 & 33,2 \\
\hline 4650 - 6974 (2- 3 Asgari Ücret Arası) & 253 & 43,3 \\
\hline 6975 ve üzeri ( 3 Asgari Ücret ve Fazlası) & 137 & 23,5 \\
\hline Toplam & 584 & 100 \\
\hline \multicolumn{3}{|c|}{ Pozisyon Grup } \\
\hline
\end{tabular}


M. Özdemir - A. Doğan 13/3 (2021) 2203-2222

\begin{tabular}{lll}
\hline Yönetsel Olmayan Emek Yoğun & 110 & 18,8 \\
\hline Yönetsel Olmayan Bilgi Yoğun & 279 & 47,8 \\
\hline Yönetici & 195 & 33,4 \\
\hline Toplam & $\mathbf{5 8 4}$ & $\mathbf{1 0 0}$ \\
\hline
\end{tabular}

İşe tutkunluk ve alt faktörlerine yönelik betimleyici istatistikler Tablo 7'de yer almaktadır. Tablo incelendiğinde ölçek geneli ve alt faktörlerinin çarpıklık ve basıklık değerlerine göre normal dağılıma uygun olduğu görülmektedir. Ayrıca işe tutkunluk faktörlerinden yoğunlaşmanın diğer faktörlere göre daha düşük bir ortalamaya sahip olduğu, standart sapmasının ise hem ölçek geneli hem de faktörler arasındaki en yüksek değere sahip olduğu görülmektedir.

Tablo 7. İşe Tutkunluk Ölçeği Betimleyici İstatistikler

\begin{tabular}{|c|c|c|c|c|c|c|c|}
\hline & $\mathbf{N}$ & Min. & Maks. & Ort. & Std. Sapma & Çarpı1klık & Basıklık \\
\hline Dinçlik & \multirow{4}{*}{584} & 1,00 & 7,00 & 5,5442 & 1,27472 & $-1,108$ & 878 \\
\hline Adanma & & 1,50 & 7,00 & 5,5879 & 1,05598 &,- 896 & 475 \\
\hline Yoğunlaşma & & 1,00 & 7,00 & 4,6809 & 1,33775 &,- 387 &,- 407 \\
\hline İşe Tutkunluk Genel & & 1,20 & 7,00 & 5,3890 & 1,04903 &,- 830 & ,366 \\
\hline
\end{tabular}

Araştırmanın birinci hipotezi olan " $\mathrm{H}_{1}$ : Bireylerin çalışma düşüncesine göre işe tutkunluk düzeylerinde farklılık vardır." hipotezi ve alt hipotezlerinin incelenmesi amacıyla çalışma düşüncesi gruplarının işe tutkunluk ve alt faktörlerine göre farklılığın incelenmesi amacıyla tek yönlü varyans (one-way Anova) analizi yapılmıştır. Katılımcıların çalışma düşüncelerine göre, işe tutkunluk ve alt faktörlerinin ortalamaları Tablo 8'de görülmektedir. Katılımcıların benimsedikleri çalışma düşüncelerine en yüksek katılım gösterilen görüşten en düşüğe doğru sıralaması ÇD2-Özgürlük (153 kişi), ÇD3- Meta (94 kişi), ÇD9- Kimlik (61 kişi), ÇD6- Kişisel Tatmin (54 kişi), ÇD1- Lanet (53 kişi), ÇD10- Hizmet (44 kişi), ÇD5- Izdırap (30 kişi), ÇD8Başkalarına Bakma (26 kişi), ÇD4- Mesleki Vatandaşlık (25 kişi), ÇD7- Sosyal İlişki (23 kişi), ÇD11- Diğer (21 kişi) şeklindedir.

Tablo 8. Çalışma Düşüncesine Göre İşe Tutkunluk ve Faktörlerinin Ortalamaları

\begin{tabular}{lccccccc}
\hline Çalışma Düşüncesi & $\mathbf{N}$ & $\mathbf{\%}$ & $\begin{array}{c}\text { Kümülatif } \\
\mathbf{\%}\end{array}$ & $\begin{array}{c}\text { Dinçlik } \\
\text { Ort. }\end{array}$ & $\begin{array}{c}\text { Adanma } \\
\text { Ort. }\end{array}$ & $\begin{array}{c}\text { Yoğunlaşma } \\
\text { Ort. }\end{array}$ & $\begin{array}{c}\text { İşe } \\
\text { Tutkunluk } \\
\text { Genel Ort. }\end{array}$ \\
\hline ÇD1- Lanet & 53 & 9,10 & 9,10 & 5,01 & 5,19 & 3,97 & 4,87 \\
\hline ÇD2- Özgürlük & 153 & 26,20 & 35,30 & 6,06 & 5,98 & 5,07 & 5,83 \\
\hline ÇD3- Meta & 94 & 16,10 & 51,40 & 4,88 & 5,16 & 4,23 & 4,86 \\
\hline ÇD4- Mesleki Vatandaşlık & 25 & 4,30 & 55,70 & 5,71 & 5,67 & 4,41 & 5,44 \\
\hline ÇD5- Izdırap & 30 & 5,10 & 60,80 & 4,84 & 4,71 & 4,02 & 4,62 \\
\hline ÇD6- Kişisel Tatmin & 54 & 9,20 & 70,00 & 5,56 & 5,43 & 4,84 & 5,36 \\
\hline ÇD7- Sosyal İlişki & 23 & 3,90 & 74,00 & 5,73 & 5,48 & 5,12 & 5,51 \\
\hline ÇD8- Başkalarına Bakma & 26 & 4,50 & 78,40 & 5,37 & 5,99 & 4,65 & 5,48 \\
\hline ÇD9- Kimlik & 61 & 10,40 & 88,90 & 5,78 & 5,83 & 4,83 & 5,61 \\
\hline ÇD10- Hizmet & 44 & 7,50 & 96,40 & 5,79 & 5,81 & 4,98 & 5,63 \\
\hline ÇD11- Diğer & 21 & 3,60 & 100,00 & 5,63 & 5,66 & 5,03 & 5,52 \\
\hline Toplam & 584 & & 100,00 & 5,54 & 5,59 & 4,68 & 5,39 \\
\hline
\end{tabular}

Tablo 9'da yer alan gruplar arası varyans homojenliğine ilişkin analiz sonuçları incelendiğinde adanma ve yoğunlaşma faktörlerinin istatistik değerleri 0,05 ten büyük (adanma $=, 072$; yoğunlaşma $=, 665$ ) olduğundan grup varyanslarının eşit varsayıldığı, dinçlik ve işe tutkunluk genelinin grup varyanslarının eşit varsayılmadığ $1(p<0,05)$ görülmektedir. 
M. Özdemir - A. Doğan 13/3 (2021) 2203-2222

Tablo 9. İşe Tutkunluk ve Faktörlerinin Çalışma Düşüncesi Gruplarına Göre Varyans Homojenliği Testi

\begin{tabular}{lcccc}
\hline & Levene İstatistiği & Sd1 & Sd2 & p \\
\hline Dinçlik & 3,871 & 10 & 573 &, 000 \\
\hline Adanma & 1,723 & 10 & 573 &, 072 \\
\hline Yoğunlaşma &, 762 & 10 & 573 &, 665 \\
\hline İşe Tutkunluk Genel & 1,970 & 10 & 573 &, 034 \\
\hline
\end{tabular}

Çalışma düşüncesine göre işe tutkunluk düzeylerine ilişkin Anova analizinin sonuçları Tablo 10'da görülmektedir. Tabloda yer alan Anova istatistikleri incelendiğinde tüm faktörler ve ölçek geneli p değerinin 0,05 değerinden küçük olduğu görülmektedir. Buna göre hem işe tutkunluğun genelinde hem de alt faktörlerinde çalışma düşüncesine göre istatistiki olarak anlamlı farklılık olduğu söylenebilir.

Tablo 10. Çalışma Düşüncesine Göre İşe Tutkunluk Anova Analiz Sonuçları

\begin{tabular}{|c|c|c|c|c|c|c|}
\hline & & Kareler Toplamı & sd & Ortalama Kare & $\mathbf{F}$ & $p$ \\
\hline \multirow{3}{*}{ Dinçlik } & Gruplar Arası & 120,952 & 10 & 12,095 & 8,387 & 2,000 \\
\hline & Gruplar İçi & 826,377 & 573 & 1,442 & & \\
\hline & Toplam & 947,329 & 583 & & & \\
\hline \multirow{3}{*}{ Adanma } & Gruplar Arası & 85,09 & 10 & 8,509 & 8,629 & ,000 \\
\hline & Gruplar İçi & 565,009 & 573 & 0,986 & & \\
\hline & Toplam & 650,099 & 583 & & & \\
\hline \multirow{3}{*}{ Yoğunlaşma } & Gruplar Arası & 97,188 & 10 & 9,719 & 5,886 &, 000 \\
\hline & Gruplar İçi & 946,138 & 573 & 1,651 & & \\
\hline & Toplam & 1043,326 & 583 & & & \\
\hline \multirow{3}{*}{$\begin{array}{l}\text { İşe Tutkunluk } \\
\text { Genel }\end{array}$} & Gruplar Arası & 94,538 & 10 & 9,454 & 9,903 & ,000 \\
\hline & Gruplar İçi & 547,036 & 573 & 0,955 & & \\
\hline & Toplam & 641,574 & 583 & & & \\
\hline
\end{tabular}

Gruplar arasındaki farklılı̆̆ın hangi gruptan kaynaklandığının incelenmesi amacıyla yapılan Post-Hoc Analizleri Tablo 11'de görülmektedir. Post- Hoc analizleri yapılırken gruplar arası eşit varyanslı kabul edilen adanma ve yoğunlaşma için Scheffe, eşit varyanslı kabul edilmeyen dinçlik ve işe tutkunluk ölçek geneli için Dunnet $\mathrm{C}$ testi yapılmıştır.

Tablo 11. Çalışma Düşüncesi İşe Tutkunluk Anova Analizi Post-Hoc Testleri

\begin{tabular}{|c|c|c|c|}
\hline & (I) Çalışma Düşüncesi & & Ortalama Farkı (I-J) \\
\hline \multirow{5}{*}{ Dinçlik } & \multirow{3}{*}{ Özgürlük } & Lanet & $1,04951^{*}$ \\
\hline & & Meta & $1,18089^{*}$ \\
\hline & & Izdirap & $1,22320^{*}$ \\
\hline & Kimlik & Meta & ,90295* \\
\hline & Hizmet & Meta & ,91046* \\
\hline \multirow{6}{*}{ Adanma } & \multirow{3}{*}{ Özgürlük } & Lanet & ,79921* \\
\hline & & Meta & $82695^{*}$ \\
\hline & & Izdirap & $1,27364^{*}$ \\
\hline & \multirow{3}{*}{ Izdırap } & Başkalarına Bakma & $-1,28248^{*}$ \\
\hline & & Kimlik & $-1,11949^{*}$ \\
\hline & & Hizmet & $-1,09571^{*}$ \\
\hline \multirow{2}{*}{ Yoğunlaşma } & \multirow{2}{*}{ Özgürlük } & Lanet & $1,09898^{*}$ \\
\hline & & Meta &, $83704^{*}$ \\
\hline \multirow{6}{*}{$\begin{array}{l}\text { İşe } \\
\text { Tutkunluk } \\
\text { Genel }\end{array}$} & \multirow{3}{*}{ Özgürlük } & Lanet & ,95929* \\
\hline & & Meta & ,97054* \\
\hline & & Izdirap & $1,20780^{*}$ \\
\hline & \multirow{3}{*}{ Kimlik } & Lanet & ,73907* \\
\hline & & Meta & $75032^{*}$ \\
\hline & & Izdirap & ,98758* \\
\hline
\end{tabular}


Hizmet

\begin{tabular}{lc} 
Lanet &, $76189^{*}$ \\
\hline Meta &, $77315^{*}$ \\
\hline Izdirap & $1,01040^{*}$
\end{tabular}

Tablo 11'deki Post-Hoc analizlerinden görüleceği üzere çalışmayı özgürlük olan değerlendiren bireylerin, dinçlik düzeylerinin, çalışmayı lanet, meta ve ızdırap olarak değerlendirenlerden anlamlı şekilde yüksek olduğu, benzer şekilde çalışmayı kimlik ve hizmet olarak değerlendiren bireylerin çalışmayı meta olarak değerlendirenlere göre daha yüksek düzeyde dinçlik ortalamasına sahip olduğu görülmektedir.

Adanma boyutuna göre incelendiğinde ise çalışmayı özgürlük olarak değerlendiren bireylerin, lanet meta ve ızdırap olarak değerlendirenlerden daha yüksek adanma ortalamasına sahip olduğu görülmektedir. Çalışmayı başkalarına bakma, kimlik ve hizmet olarak değerlendiren bireylerin izdırap olarak değerlendirenlere göre daha yüksek adanma düzeylerine sahip olduğu söylenebilir.

Yoğunlaşma boyutu incelendiğinde çalışmayı özgürlük olarak değerlendiren bireylerin, lanet ve meta olarak değerlendiren bireylere göre daha yüksek yoğunlaşma düzeyine sahip olduğu görülmektedir.

Genel olarak işe tutkunluk düzeyleri incelendiğinde, çalışmayı özgürlük, kimlik ve hizmet olarak değerlendiren bireylerin işe tutkunluk ortalamalarının, çalışmayı meta, lanet ve izdırap olarak değerlendiren gruplardan istatitiki olarak anlamlı derecede yüksek olduğu görülmektedir.

İşe tutkunluk boyutlarına göre kümeleme analizi yapıldığında Tablo 12' de görüldüğg̈ü üzere birbirinden farklı 3 grup oluştuğu görülmektedir. Grupların işe tutkunluk ve boyutlarının ortalamaları incelendiğinde, söz konusu grupların yüksek, orta ve düşük işe tutkunluk düzeylerine göre oluştuğu görülmektedir.

Tablo 12. İşe Tutkunluk ve Boyutlarının Kümeleme Analiz Sonuçları

\begin{tabular}{|c|c|c|c|c|c|c|c|c|}
\hline & \multicolumn{2}{|c|}{ Dinçlik } & \multicolumn{2}{|c|}{ Adanma } & \multicolumn{2}{|c|}{ Yoğunlaşma } & \multicolumn{2}{|c|}{ İșe Tutkunluk Genel } \\
\hline & Ort. & Std Sapma & Ort. & Std Sapma & Ort. & Std Sapma & Ort. & Std Sapma \\
\hline Yükssek & 6,4442 & ,48209 & 6,3578 & , 47641 & 5,7193 & ,76380 & 6,2647 & ,36752 \\
\hline Orta & 5,4076 & ,75334 & 5,3795 & ,61212 & 4,1045 & ,93344 & 5,1358 & ,37322 \\
\hline Düşük & 3,4082 & ,98822 & 3,9660 & 92439 & 3,1565 & 1,06620 & 3,5810 & 61624 \\
\hline
\end{tabular}

Kümeleme analiz sonuçlarının çalışma düşüncesi gruplarına göre dağılımı Şekil 3'te yer almaktadır.

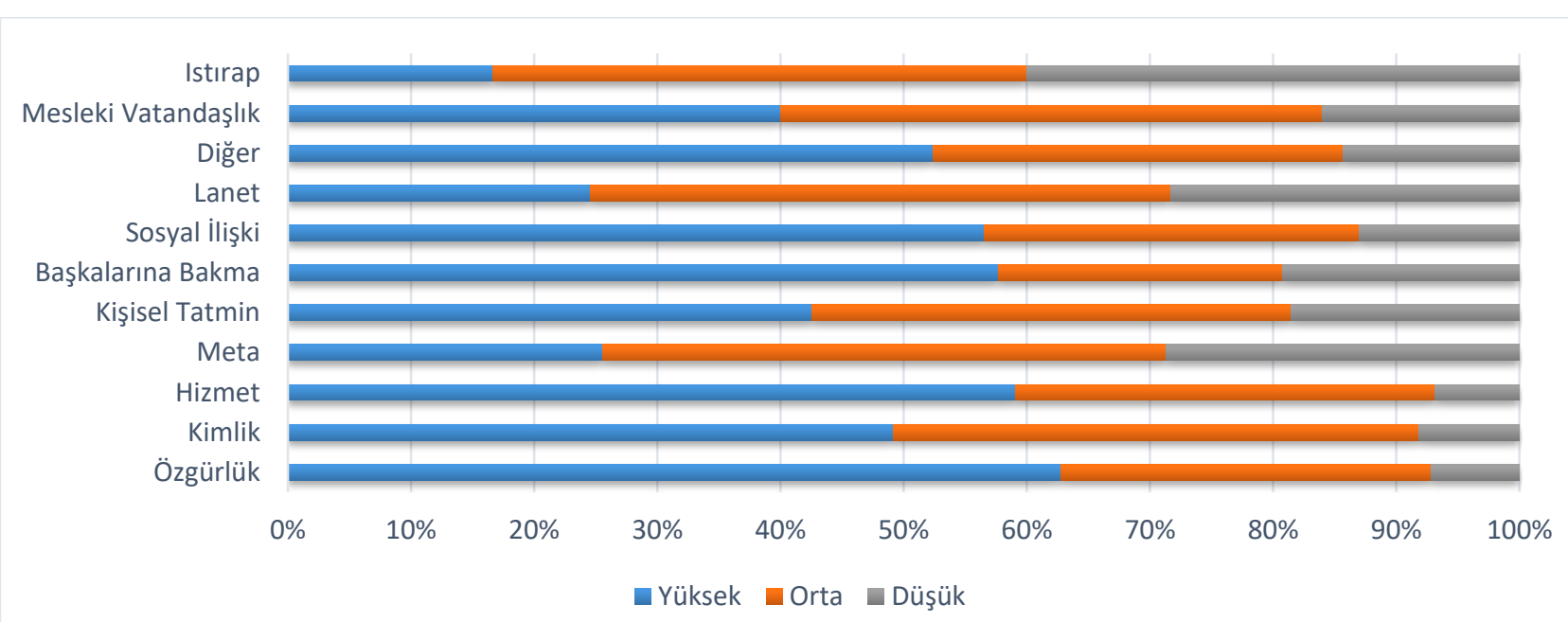

Şekil 3. Kümeleme Sonuçlarının Çalışma Düşüncesine Göre Dağılımı

Tablo incelendiğinde, çalışmayı özgürlük, hizmet ve kimlik olarak gören bireylerin \%90'dan fazlası orta ve yüksek \%10'undan azı düşük düzeyde işe tutkunluk değerlendirmesine sahiptir. Çalışmayı, ızdırap, lanet ve meta olarak değerlendirenlerin yaklaşık \% 24'ü yüksek düzeyde işe tutkunluk değerlendirmesine sahiptir. Çalışmayı, mesleki vatandaşlık, sosyal ilişki, başkalarına bakma, kişisel tatmin olarak değerlendiren bireylerin işe tutkunluk düzeylerinin diğer gruplardan istatistiki olarak anlamlı bir şekilde farklılık göstermediği söylenebilir. 
M. Özdemir - A. Doğan 13/3 (2021) 2203-2222

Araştırmanın ikinci hipotezi ( $\mathrm{H}_{2}$ : Demografik özelliklere göre çalışma düşüncesinde farklılık vardır.) ve alt hipotezlerinin incelenmesi için Ki-Kare Analizi yapılmıştır. Tablo 13' de yer alan çarpraz tabloda katılımcıların demografik özelliklerine çalışma düşüncelerine ilişkin frekanslar, beklenen değerler ve düzeltilmiş atık değerleri görülmektedir.

Tablo 13. Katılımcıların Demografik Özellikleri ve Çalışma Düşüncesi Çarpraz Tablosu

\begin{tabular}{|c|c|c|c|c|c|c|c|c|c|c|c|c|c|c|c|}
\hline & \multicolumn{3}{|c|}{ Cinsiyet } & \multicolumn{3}{|c|}{ M. Durum } & \multicolumn{3}{|c|}{ Öğrenim } & \multicolumn{5}{|c|}{ Yas } \\
\hline & & Erk. & $\mathrm{Kdn}$ & T. & $\mathrm{Bkr}$ & Evli & T. & Önlsn & Lisns & L.Üst & $\mathrm{T}$. & $18-34$ & $35-44$ & $45+$ & T. \\
\hline \multirow{3}{*}{$\overline{\theta_{n}}$} & Değer & 29 & 24 & 53 & 18 & 35 & 53 & 18 & 26 & 9 & 53 & 17 & 25 & 11 & 53 \\
\hline & B.Değer & 22 & 31,1 & 53 & 16 & 36,8 & 53 & 13,3 & 28 & 11,6 & 53 & 15,2 & 20,6 & 17 & 53 \\
\hline & D. Atık & 2,1 & $-2,1$ & & 0,5 & $-0,5$ & & 1,5 & $-0,6$ & $-0,9$ & & 0,6 & 1,3 & $-1,9$ & \\
\hline \multirow{3}{*}{ อิ } & Değer & 39 & 114 & 153 & 46 & 107 & 153 & 38 & 86 & 29 & 153 & 44 & 54 & 55 & 153 \\
\hline & B.Değer & 63 & 89,9 & 153 & 47 & 106 & 153 & 38,5 & 81 & 33,5 & 153 & 44 & 59,5 & 50 & 153 \\
\hline & D. Atık & $-4,6$ & 4,6 & & $-0,2$ & 0,2 & & $-0,1$ & 1 & -1 & & 0 & $-1,1$ & 1,1 & \\
\hline \multirow{3}{*}{$\stackrel{m}{\tilde{u}}$} & Değer & 51 & 43 & 94 & 28 & 66 & 94 & 22 & 47 & 25 & 94 & 30 & 39 & 25 & 94 \\
\hline & B.Değer & 39 & 55,2 & 94 & 29 & 65,2 & 94 & 23,7 & 49,7 & 20,6 & 94 & 27 & 36,5 & 30 & 94 \\
\hline & D. Atık & 2,8 & $-2,8$ & & $-0,2$ & 0,2 & & $-0,4$ & $-0,6$ & 1,2 & & 0,7 & 0,6 & $-1,3$ & \\
\hline \multirow{3}{*}{$\stackrel{H}{u^{\prime}}$} & Değer & 8 & 17 & 25 & 6 & 19 & 25 & 15 & 8 & 2 & 25 & 6 & 2 & 17 & 25 \\
\hline & B.Değer & 10 & 14,7 & 25 & 7,7 & 17,3 & 25 & 6,3 & 13,2 & 5,5 & 25 & 7,2 & 9,7 & 8,1 & 25 \\
\hline & D. Atık & -1 & 1 & & $-0,7$ & 0,7 & & 4,1 & $-2,1$ & $-1,7$ & & $-0,5$ & $-3,2$ & 3,9 & \\
\hline \multirow{3}{*}{$\stackrel{\text { en }}{\mathrm{u}^{\prime}}$} & Değer & 18 & 12 & 30 & 15 & 15 & 30 & 2 & 18 & 10 & 30 & 16 & 8 & 6 & 30 \\
\hline & B.Değer & 12 & 17,6 & 30 & 9,2 & 20,8 & 30 & 7,6 & 15,9 & 6,6 & 30 & 8,6 & 11,7 & 9,7 & 30 \\
\hline & D. Atık & 2,1 & $-2,1$ & & 2,4 & $-2,4$ & & $-2,4$ & 0,8 & 1,6 & & 3,1 & $-1,4$ & $-1,5$ & \\
\hline \multirow{3}{*}{ 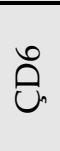 } & Değer & 18 & 36 & 54 & 18 & 36 & 54 & 8 & 28 & 18 & 54 & 18 & 20 & 16 & 54 \\
\hline & B.Değer & 22 & 31,7 & 54 & 17 & 37,4 & 54 & 13,6 & 28,6 & 11,8 & 54 & 15,5 & 21 & 18 & 54 \\
\hline & D. Atık & $-1,2$ & 1,2 & & 0,4 & $-0,4$ & & $-1,8$ & $-0,2$ & 2,1 & & 0,8 & $-0,3$ & $-0,5$ & \\
\hline \multirow{3}{*}{$\hat{\mathrm{e}}$} & Değer & 11 & 12 & 23 & 5 & 18 & 23 & 0 & 16 & 7 & 23 & 5 & 14 & 4 & 23 \\
\hline & B.Değer & 9,5 & 13,5 & 23 & 7 & 16 & 23 & 5,8 & 12,2 & 5 & 23 & 6,6 & 8,9 & 7,4 & 23 \\
\hline & D. Attk & 0,7 & $-0,7$ & & $-0,9$ & 0,9 & & $-2,8$ & 1,6 & 1 & & $-0,8$ & 2,2 & $-1,6$ & \\
\hline \multirow{3}{*}{$\stackrel{\infty}{\theta^{\prime}}$} & Değer & 10 & 16 & 26 & 8 & 18 & 26 & 7 & 16 & 3 & 26 & 5 & 12 & 9 & 26 \\
\hline & B.Değer & 11 & 15,3 & 26 & 8 & 18 & 26 & 6,5 & 13,8 & 5,7 & 26 & 7,5 & 10,1 & 8,4 & 26 \\
\hline & D. Atık & $-0,3$ & 0,3 & & 0 & 0 & & 0,2 & 0,9 & $-1,3$ & & $-1,1$ & 0,8 & 0,3 & \\
\hline \multirow{3}{*}{ 仓̊. } & Değer & 28 & 33 & 61 & 15 & 46 & 61 & 15 & 36 & 10 & 61 & 15 & 26 & 20 & 61 \\
\hline & B.Değer & 25 & 35,8 & 61 & 19 & 42,3 & 61 & 15,4 & 32,3 & 13,4 & 61 & 17,5 & 23,7 & 20 & 61 \\
\hline & D. Atık & 0,8 & $-0,8$ & & $-1,1$ & 1,1 & & $-0,1$ & 1 & $-1,1$ & & $-0,8$ & 0,6 & 0,1 & \\
\hline \multirow{3}{*}{$\stackrel{\circ}{\overrightarrow{0}}$} & Değer & 20 & 24 & 44 & 16 & 28 & 44 & 15 & 19 & 10 & 44 & 8 & 15 & 21 & 44 \\
\hline & B.Değer & 18 & 25,8 & 44 & 14 & 30,5 & 44 & 11,1 & 23,3 & 9,6 & 44 & 12,7 & 17,1 & 14 & 44 \\
\hline & D. Atık & 0,6 & $-0,6$ & & 0,9 & $-0,9$ & & 1,4 & $-1,3$ & 0,1 & & $-1,6$ & $-0,7$ & 2,3 & \\
\hline \multirow{3}{*}{$\overrightarrow{\bar{\theta}}$} & Değer & 9 & 12 & 21 & 4 & 17 & 21 & 7 & 9 & 5 & 21 & 4 & 12 & 5 & 21 \\
\hline & B.Değer & 8,7 & 12,3 & 21 & 6,4 & 14,6 & 21 & 5,3 & 11,1 & 4,6 & 21 & 6 & 8,2 & 6,8 & 21 \\
\hline & D. Atık & 0,2 & $-0,2$ & & $-1,2$ & 1,2 & & 0,9 & $-0,9$ & 0,2 & & -1 & 1,7 & $-0,9$ & \\
\hline
\end{tabular}


M. Özdemir - A. Doğan 13/3 (2021) 2203-2222

Tablo 13 (Devamı). Katılımcıların Demografik Özellikleri ve Çalışma Düşüncesi Çarpraz Tablosu

\begin{tabular}{|c|c|c|c|c|c|c|c|c|c|c|c|c|c|c|c|c|}
\hline & & \multicolumn{4}{|c|}{ Pozisyon } & \multicolumn{3}{|c|}{ Sektör } & \multicolumn{4}{|c|}{ Çalışma Suresi (Yıl) } & \multicolumn{3}{|c|}{ Ücret } & \multirow[b]{2}{*}{ T. } \\
\hline & & $\begin{array}{c}\text { E. } \\
\text { Yoğn }\end{array}$ & $\begin{array}{c}\text { B. } \\
\text { Yoğn }\end{array}$ & Yön & T. & $\mathrm{Kmu}$ & Özl & $\mathrm{T}$. & $1-9$ & 10-19 & $20+$ & $\mathrm{T}$. & $\begin{array}{l}1-2 \\
\mathrm{AÜ}\end{array}$ & $\begin{array}{l}2-3 \\
A \ddot{U}\end{array}$ & $\begin{array}{c}3+ \\
\mathrm{AU}\end{array}$ & \\
\hline \multirow{3}{*}{$\overrightarrow{0}$} & Değer & 9 & 27 & 17 & 53 & 26 & 27 & 53 & 19 & 19 & 15 & 53 & 25 & 13 & 15 & 53 \\
\hline & B.Değer & 10 & 25,3 & 17,7 & 53 & 27,6 & 25,4 & 53 & 16,3 & 16,2 & 21 & 53 & 17,6 & 23 & 12,4 & 53 \\
\hline & D. Atık & $-0,4$ & 0,5 & $-0,2$ & & $-0,5$ & 0,5 & & 0,8 & 0,9 & $-1,6$ & & 2,3 & $-2,9$ & 0,9 & \\
\hline \multirow{3}{*}{ อิ } & Değer & 24 & 68 & 61 & 153 & 87 & 66 & 153 & 49 & 43 & 61 & 153 & 52 & 71 & 30 & 153 \\
\hline & B.Değer & 28,8 & 73,1 & 51,1 & 153 & 79,6 & 73,4 & 153 & 47,2 & 46,6 & 59 & 153 & 50,8 & 66,3 & 35,9 & 153 \\
\hline & D. Atık & $-1,2$ & -1 & 2 & & 1,4 & $-1,4$ & & 0,4 & $-0,7$ & 0,3 & & 0,2 & 0,9 & $-1,3$ & \\
\hline \multirow{3}{*}{$\stackrel{\rho}{\rho}$} & Değer & 19 & 49 & 26 & 94 & 39 & 55 & 94 & 31 & 33 & 30 & 94 & 26 & 43 & 25 & 94 \\
\hline & B.Değer & 17,7 & 44,9 & 31,4 & 94 & 48,9 & 45,1 & 94 & 29 & 28,7 & 36 & 94 & 31,2 & 40,7 & 22,1 & 94 \\
\hline & D. Atık & 0,4 & 0,9 & $-1,3$ & & $-2,2$ & 2,2 & & 0,5 & 1,1 & $-1,5$ & & $-1,2$ & 0,5 & 0,8 & \\
\hline \multirow{3}{*}{ 巳 } & Değer & 9 & 9 & 7 & 25 & 19 & 6 & 25 & 3 & 4 & 18 & 25 & 7 & 15 & 3 & 25 \\
\hline & B.Değer & 4,7 & 11,9 & 8,3 & 25 & 13 & 12 & 25 & 7,7 & 7,6 & 9,7 & 25 & 8,3 & 10,8 & 5,9 & 25 \\
\hline & D. Atık & 2,2 & $-1,2$ & $-0,6$ & & 2,4 & $-2,4$ & & $-2,1$ & $-1,6$ & 3,5 & & $-0,6$ & 1,7 & $-1,4$ & \\
\hline \multirow{3}{*}{$\stackrel{\text { อ̊ }}{\mathcal{U}^{\prime}}$} & Değer & 3 & 20 & 7 & 30 & 12 & 18 & 30 & 17 & 6 & 7 & 30 & 12 & 9 & 9 & 30 \\
\hline & B.Değer & 5,7 & 14,3 & 10 & 30 & 15,6 & 14,4 & 30 & 9,2 & 9,1 & 12 & 30 & 10 & 13 & 7 & 30 \\
\hline & D. Atık & $-1,3$ & 2,1 & $-1,2$ & & $-1,4$ & 1,4 & & 3,1 & $-1,3$ & $-1,8$ & & 0,8 & $-1,5$ & 0,9 & \\
\hline \multirow{3}{*}{$\stackrel{\circ}{0}$} & Değer & 8 & 24 & 22 & 54 & 25 & 29 & 54 & 19 & 12 & 23 & 54 & 14 & 24 & 16 & 54 \\
\hline & B.Değer & 10,2 & 25,8 & 18 & 54 & 28,1 & 25,9 & 54 & 16,6 & 16,5 & 21 & 54 & 17,9 & 23,4 & 12,7 & 54 \\
\hline & D. Atık & $-0,8$ & $-0,5$ & 1,2 & & $-0,9$ & 0,9 & & 0,7 & $-1,4$ & 0,6 & & $-1,2$ & 0,2 & 1,1 & \\
\hline \multirow{3}{*}{$\hat{\mathrm{U}}$} & Değer & 3 & 12 & 8 & 23 & 14 & 9 & 23 & 7 & 7 & 9 & 23 & 8 & 11 & 4 & 23 \\
\hline & B.Değer & 4,3 & 11 & 7,7 & 23 & 12 & 11 & 23 & 7,1 & 7 & 8,9 & 23 & 7,6 & 10 & 5,4 & 23 \\
\hline & D. Atık & $-0,7$ & 0,4 & 0,1 & & 0,9 & $-0,9$ & & 0 & 0 & 0 & & 0,2 & 0,4 & $-0,7$ & \\
\hline \multirow{3}{*}{$\stackrel{\infty}{\rho}$} & Değer & 8 & 9 & 9 & 26 & 14 & 12 & 26 & 6 & 7 & 13 & 26 & 8 & 13 & 5 & 26 \\
\hline & B.Değer & 4,9 & 12,4 & 8,7 & 26 & 13,5 & 12,5 & 26 & 8 & 7,9 & 10 & 26 & 8,6 & 11,3 & 6,1 & 26 \\
\hline & D. Atık & 1,6 & $-1,4$ & 0,1 & & 0,2 & $-0,2$ & & $-0,9$ & $-0,4$ & 1,2 & & $-0,3$ & 0,7 & $-0,5$ & \\
\hline \multirow{3}{*}{ อิ } & Değer & 15 & 32 & 14 & 61 & 32 & 29 & 61 & 15 & 25 & 21 & 61 & 21 & 25 & 15 & 61 \\
\hline & B.Değer & 11,5 & 29,1 & 20,4 & 61 & 31,8 & 29,2 & 61 & 18,8 & 18,6 & 24 & 61 & 20,3 & 26,4 & 14,3 & 61 \\
\hline & D. Atık & 1,2 & 0,8 & $-1,8$ & & 0,1 & $-0,1$ & & $-1,1$ & 1,9 & $-0,7$ & & 0,2 & $-0,4$ & 0,2 & \\
\hline \multirow{3}{*}{$\stackrel{\circ}{\stackrel{\vec{\rho}}{e}}$} & Değer & 8 & 22 & 14 & 44 & 28 & 16 & 44 & 7 & 14 & 23 & 44 & 13 & 20 & 11 & 44 \\
\hline & B.Değer & 8,3 & 21 & 14,7 & 44 & 22,9 & 21,1 & 44 & 13,6 & 13,4 & 17 & 44 & 14,6 & 19,1 & 10,3 & 44 \\
\hline & D. Atık & $-0,1$ & 0,3 & $-0,2$ & & 1,6 & $-1,6$ & & $-2,2$ & 0,2 & 1,9 & & $-0,5$ & 0,3 & 0,3 & \\
\hline \multirow{3}{*}{$\stackrel{\vec{\rho}}{\rho}}$. & Değer & 4 & 7 & 10 & 21 & 8 & 13 & 21 & 7 & 8 & 6 & 21 & 8 & 9 & 4 & 21 \\
\hline & B.Değer & 4 & 10 & 7 & 21 & 10,9 & 10,1 & 21 & 6,5 & 6,4 & 8,1 & 21 & 7 & 9,1 & 4,9 & 21 \\
\hline & D. Attk & 0 & $-1,3$ & 1,4 & & $-1,3$ & 1,3 & & 0,3 & 0,8 & -1 & & 0,5 & 0 & $-0,5$ & \\
\hline
\end{tabular}

Cinsiyete göre çalışma düşüncesinin farklılaşıp farklılaşmadığı incelendiğinde Tablo 14'te yer alan Ki-Kare test sonucunun $p=, 000$ olduğu görülmektedir. Buna göre $p$ değeri 0,05 değerinden küçük olduğu için bireylerin cinsiyetine göre çalışma düşüncesinde istatistiki olarak anlamlı farklılık olduğu söylenebilir.

Tablo 14. Cinsiyet ve Çalıșma Düşüncesi Ki-Kare Testi

\begin{tabular}{lccc}
\hline & Değer & sd & p. (2-yön) \\
\hline Pearson Ki-Kare & $35,012^{\mathrm{a}}$ & 11 &, 000 \\
\hline Olasıllk Oranı & 36,088 & 11 &, 000 \\
\hline $\mathbf{N}$ & 584 & & \\
\hline
\end{tabular}




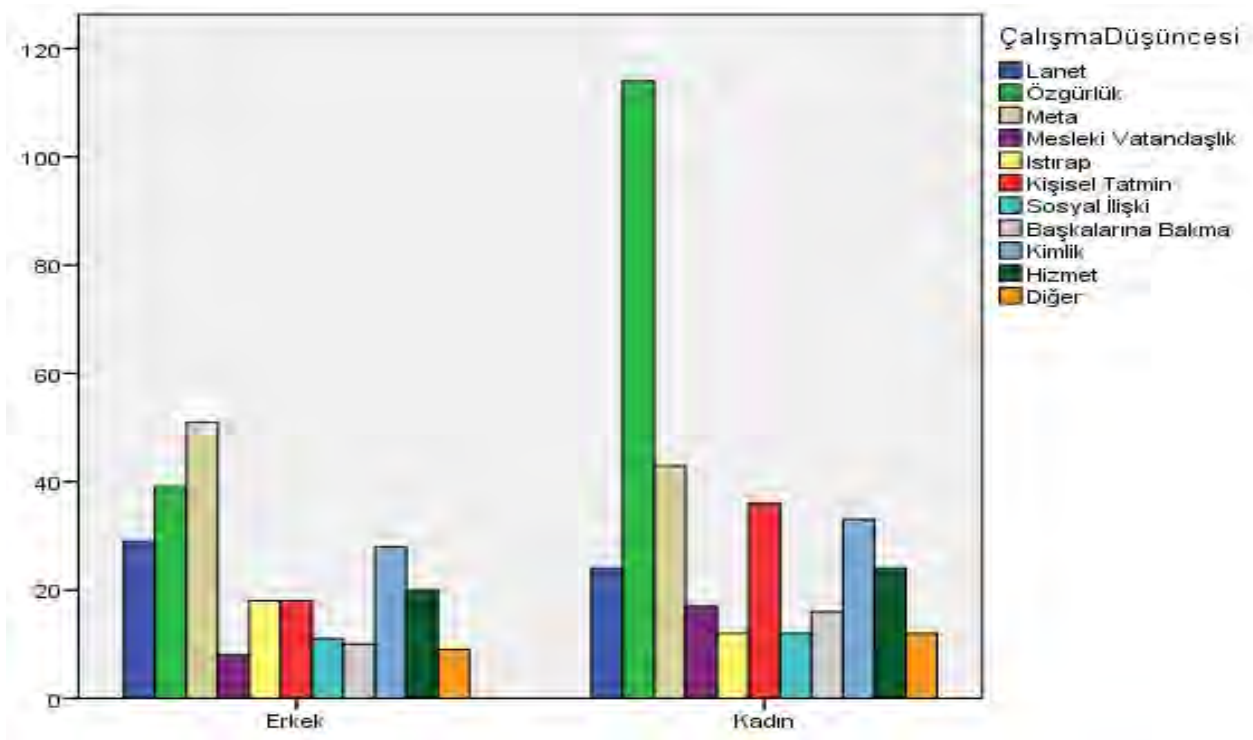

Şekil 4. Cinsiyete Göre Çalışma Düşüncesi

Çalışma düşüncesinin cinsiyete göre nasıl farklılaştığının tespit etmek için Tablo 13'te Cinsiyet ile ilgili sütunlardaki düzeltilmiş atık (D. Atık) değeri incelenmiştir. Buna göre düzeltilmiş atık değerinin mutlak değeri (0,05 anlamlılık düzeyi için $Z$ tablo değeri) 1,96'nın üzerindeki çalışma düşüncesinde istatistiki olarak anlamlı farklılı̆̆ın olduğu söylenebilir (Serper, 2004: 125). Bu kapsamda kadınlara göre daha fazla erkeğin, çalışmayı lanet (ÇD1), meta (ÇD3), ızdırap (ÇD5) olarak değerlendirdiği, buna karşılık daha fazla kadının çalışmayı özgürlük (ÇD2) olarak değerlendirdiği söylenebilir. Şekil 4'te cinsiyete göre çalışma düşüncesinin dağılımı görülmektedir.

Tablo 15 incelendiğinde Pearson Ki-Kare p değeri $(420), 05$ 'ten büyük olduğundan medeni duruma göre çalışma düşüncesinde istatistiki olarak anlamlı farklılık olmadığı görülmektedir.

Tablo 15. Medeni Durum ve Çalışma Düşüncesi Ki-Kare Testi

\begin{tabular}{llll}
\hline & Değer & sd & p (2-yön) \\
\hline Pearson Ki-Kare & 10,237 & 10 &, 420 \\
\hline Olasılık Oranı & 10,043 & 10 &, 437 \\
\hline Doğrusal- Doğrusal İlişki &, 338 & 1 &, 561 \\
\hline $\mathbf{N}$ & 584 & & \\
\hline
\end{tabular}

Bireylerin öğrenim durumlarına göre çalışma düşüncesinde farklılık olup olmadığı incelendiğinde Tablo 16 'daki Pearson Ki-Kare istatistik değerinin $(p=, 001), 05$ değerinden küçük olduğu görülmektedir. Bu durumda bireylerin öğrenim durumlarına çalışma düşüncelerinde farklılık olduğu söylenebilir. Tablo 13 ve Şekil 5 incelendiğinde önlisans ve daha düşük düzeyde öğrenim düzeyindeki bireylerin beklenenden daha fazla düzeyde "Mesleki Vatandaşlık (çalışmayı bir meslek grubuna ait olmanın yolu olarak)" değerlendirdiği görülmektedir. Çalışma düşüncesi ile ilgili olarak önlisans mezunlarının beklenenden daha az düzeyde çalışmayı ızdırap (ÇD5) ve sosyal ilişki (ÇD7) olarak gördüğü tespit edilmiştir. Öğrenim gruplarına göre çalışma düşüncesinde bir diğer farklılık ise, öğrenim düzeyi lisans üstü olan bireylerin beklenenden daha fazla düzeyde çalışmayı kişisel tatmin aracı olarak (ÇD6) değerlendirdiği söylenebilir

Tablo 16. Öğrenim Durum ve Çalışma Düşüncesi Ki-Kare Testi

\begin{tabular}{lrrc}
\hline & Değer & sd & p (2-yön) \\
\hline Pearson Ki-Kare & 46,403 & 20 &, 001 \\
\hline Olasılık Oranı & 51,128 & 20 &, 000 \\
\hline Doğrusal- Doğrusal İlişki &, 165 & 1 &, 685 \\
\hline $\mathbf{N}$ & 584 & & \\
\hline
\end{tabular}




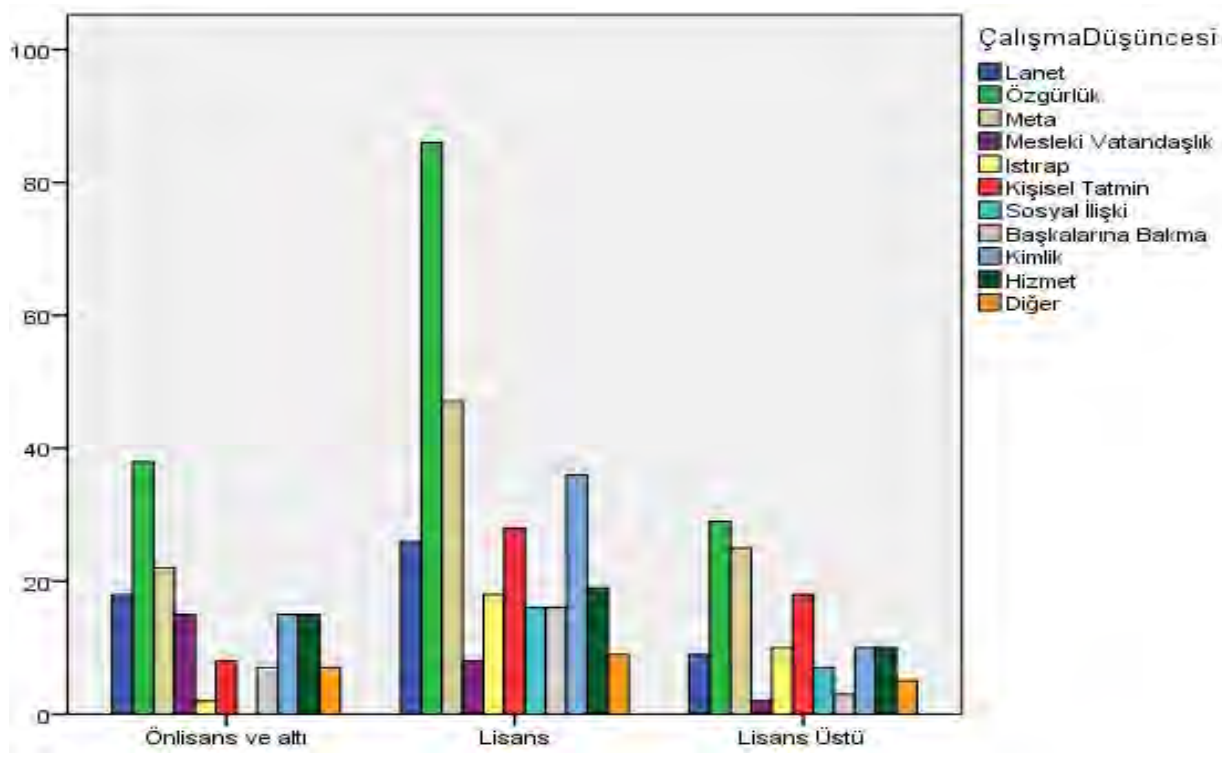

Şekil 5. Öğrenim Durumuna Göre Çalışma Düşüncesi

Tablo 17 incelendiğinde, yaş gruplarına göre çalışma düşüncesinde farklılık olduğu $(\mathrm{p}=, 001)$ görülmektedir. Tablo 13 ve Şekil 6 incelendiğinde, 18-34 yaş aralığındaki bireylerin beklenenden daha fazla çalışmayı bir maliyet (ÇD5) olarak gördüğü, 35 -44 yaş aralığındaki bireylerin beklenenden daha az düzeyde çalışmayı bir meslek grubuna ait olmanın (ÇD4) yolu olarak değerlendirdiği, beklenenden daha fazla olarak çalışmayı sosyal bir ilişki (ÇD7) biçiminde değerlendirdiği söylenebilir. 45 yaş ve üzeri grup ise 35-44 yaş grubundan farklı olarak beklenenden daha fazla şekilde çalışmayı bir meslek grubuna ait olmanın (ÇD4) ve başkalarına hizmet etmenin (yaratıcıya, ülkeye, gruba) aracı (ÇD10) olarak değerlendirmektedir.

Tablo 17. Yaş Grupları ve Çalışma Düşüncesi Ki-Kare Testi

\begin{tabular}{|c|c|c|c|}
\hline & Değer & sd & p (2-yön) \\
\hline Pearson Ki-Kare & 46,288 & 20 &, 001 \\
\hline Olasılık Oranı & 46,082 & 20 & ,001 \\
\hline Doğrusal- Doğrusal İlişki & 2,443 & 1 & 118 \\
\hline $\mathbf{N}$ & 584 & & \\
\hline $50-$ & & & 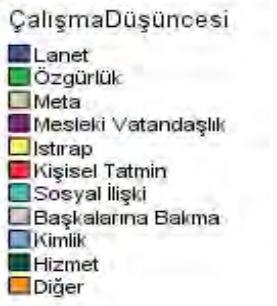 \\
\hline
\end{tabular}

Şekil 6. Yaşa Göre Çalışma Düşüncesi

Bireylerin çalıştıkları pozisyona göre çalışma düşüncesinin farklılaşıp farklılaşmadığı Tablo $18^{\prime}$ deki verilere göre incelendiğinde Pearson Ki-Kare istatistik değerinin $(p=, 222), 05$ değerinden büyük olduğu görülmektedir. 
Buna göre bireylerin, bilgi yoğun, emek yoğun veya yönetici olmalarının çalışma düşünceleri üzerinde istatistiki olarak anlamlı bir farklılığa neden olmadı̆̆ı ifade edilebilir.

Tablo 18. Pozisyon ve Çalışma Düşüncesi Ki-Kare Testi

\begin{tabular}{lccc}
\hline & Değer & sd & p (2-yön) \\
\hline Pearson Ki-Kare & 24,480 & 20 &, 222 \\
\hline Olasılık Oranı & 23,751 & 20 &, 253 \\
\hline Doğrusal- Doğrusal İlişki &, 827 & 1 &, 363 \\
\hline $\mathbf{N}$ & 584 & & \\
\hline
\end{tabular}

Kamu sektöründe ya da özel sektörde çalışıyor olmaya göre çalışma düşüncesinde farklılık olup olmadığı incelendiğinde ise Tablo $19^{\prime}$ da görüleceği üzere $(p=, 043)$ çalışılan sektöre göre çalışma düşüncesinde istatistiki olarak anlamlı farklılık olduğu görülmektedir. Bu kapsamda Tablo 13 ve Şekil 7'de görüleceği üzere özel sektörde çalışanlar beklenenden daha yüksek düzeyde çalışmayı meta (ÇD3) olarak görmekte, beklenenden daha az düzeyde çalışmayı bir mesleki vatandaşlık (ÇD4) olarak değerlendirmektedir. Kamu sektöründe çalışanlar için ise bu durum tam tersi şekildedir.

Tablo 19. Çalışılan Sektör ve Çalışma Düşüncesi Ki-Kare Testi

\begin{tabular}{lccc}
\hline & Değer & sd & p (2-yön) \\
\hline Pearson Ki-Kare & 18,778 & 10 &, 043 \\
\hline Olasılık Oranı & 19,182 & 10 &, 038 \\
\hline Doğrusal- Doğrusal İlişki &, 061 & 1 &, 806 \\
\hline $\mathbf{N}$ & 584 & & \\
\hline
\end{tabular}

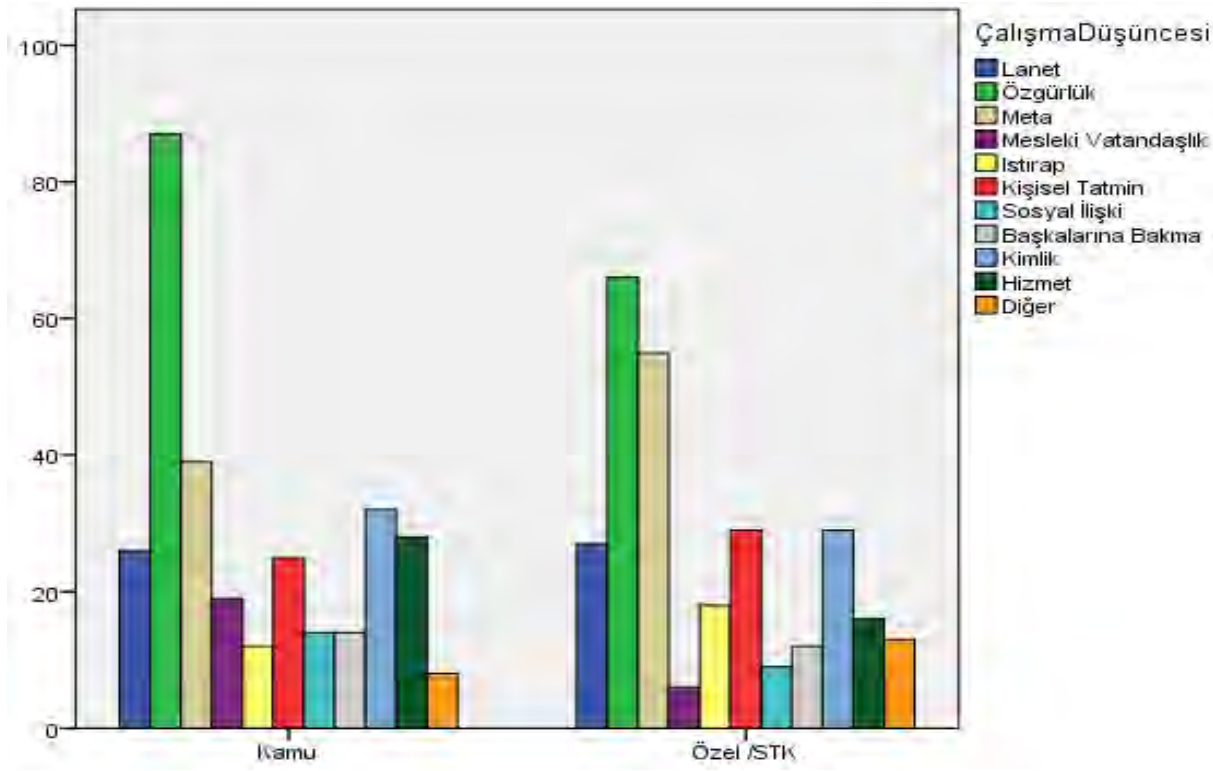

Şekil 7. Çalışılan Sektöre Göre Çalışma Düşüncesi

Tablo 20 incelendiğinde bireylerin deneyim sürelerine göre çalışma düşüncesinde istatistiki olarak anlamlı farklılı̆̆ın olduğu $(p=, 007)$ görülmektedir. Tablo 13 ve Şekil 8'de yer alan veriler incelendiğinde ise 1-9 yıl arasındaki deneyime sahip bireylerin beklenenden daha az düzeyde çalışmayı mesleki vatandaşlık (ÇD4) olarak değerlendirmekte, beklenenden daha fazla biçimde çalışmayı ızdırap (ÇD5) şeklinde değerlendirmektedir. Ayrıca 20 yıl ve daha üzerinde deneyime sahip bireyler ise beklenenden daha fazla düzeyde çalışmayı mesleki vatandaşlık (ÇD4) olarak değerlendirmektedir. 
Tablo 20. Deneyim Süresi Grupları ve Çalışma Düşüncesi Ki-Kare Testi

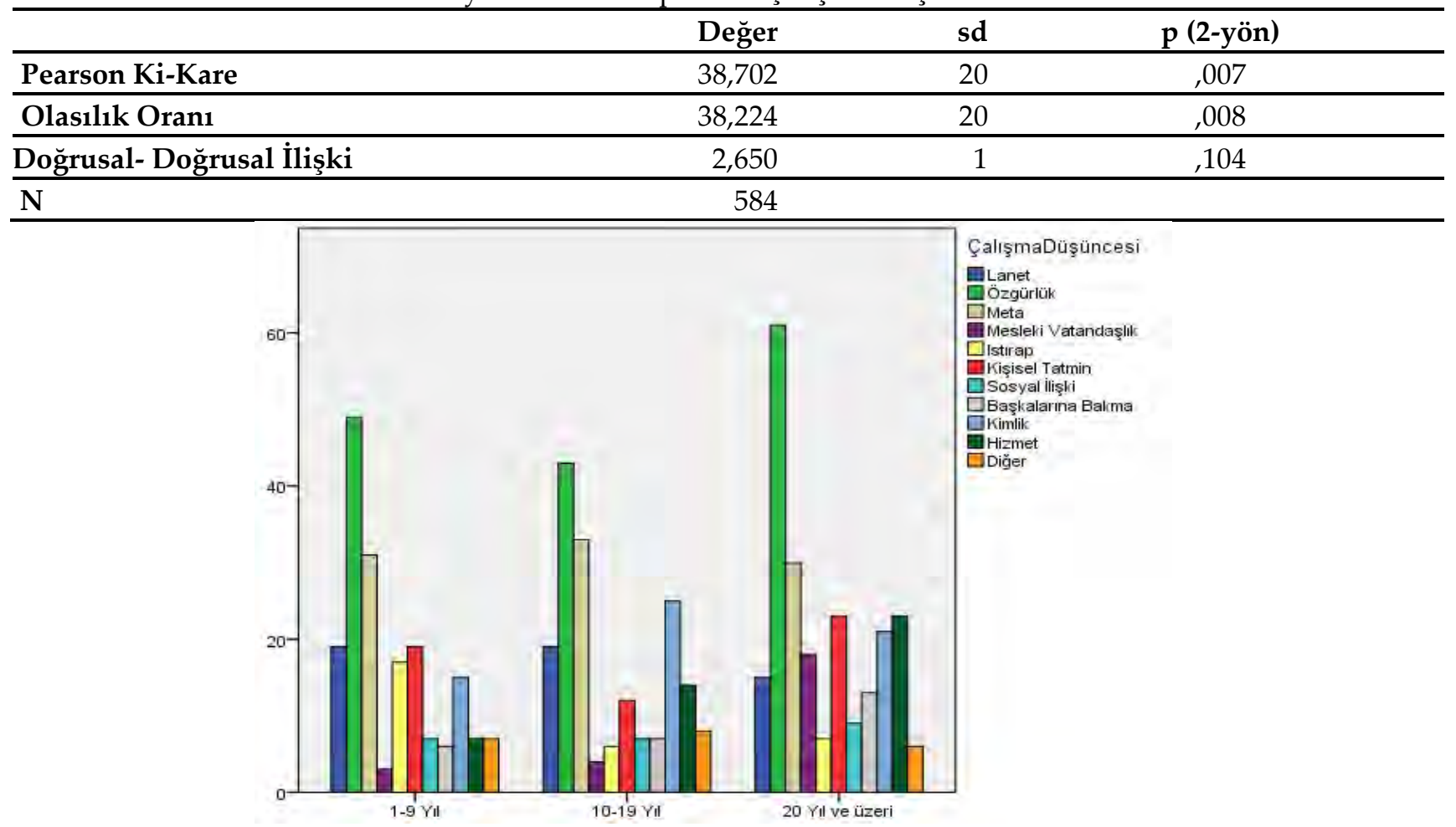

Şekil 8. Deneyim Süresine Göre Çalışma Düşüncesi

Bireylerin kazançlarına göre çalışma düşüncelerinde farklılık olup olmadığı incelendiğinde ise Tablo 21'de görüleceği üzere $(p=, 485)$ bireylerin aylık ücret gruplarına göre çalışma düşüncelerinde istatistiki olarak anlamlı farklılığın olmadığı görülmektedir.

Tablo 21. Aylık Ücret Grupları ve Çalışma Düşüncesi Ki-Kare Testi

\begin{tabular}{lccc}
\hline & Değer & sd & p (2-yön) \\
\hline Pearson Ki-Kare & 19,571 & 20 &, 485 \\
\hline Olasılık Oranı & 20,344 & 20 &, 437 \\
\hline Doğrusal- Doğrusal İlişki &, 236 & 1 &, 627 \\
\hline $\mathbf{N}$ & 584 & & \\
\hline
\end{tabular}

\section{SONUÇ VE TARTIŞMA}

Araştırma kapsamında bireylerin çalışma düşüncelerine göre işe tutkunluk düzeylerinde farklılık olup olmadığı incelendiğinde, genel olarak çalışmayı lanet, meta ve ızdırap olarak değerlendiren bireylerin işe tutkunluklarının ve dinçlik düzeylerinin çalışmayı özgürlük, kimlik ve hizmet olarak değerlendirenlere kıyasla istatistiki olarak anlamlı bir biçimde daha düşük olduğu görülmüştür.

Çalışmayı başkalarına bakma, kimlik, hizmet ve özgürlük olarak değerlendirenlerin adanma düzeyleri çalışmayı lanet, ızdırap ve meta olarak görenlere göre daha yüksektir. Bu noktada adanma boyutunda işe tutkunluğun geneli ve dinçlik boyutundan farklı olarak başkalarına bakma düşüncesine sahip bireylerin adanma düzeylerinin çalışmayı lanet, meta ve ızdırap olarak görenlerden anlamlı bir şekilde yüksek olduğu söylenebilir.

Çalışmadaki ilgi çeken bulgulardan biri de yoğunlaşma boyutunda sadece çalı̧̧mayı özgürlük olarak görenlerin çalışmayı meta ve lanet olarak görenlerden anlamlı bir şekilde yüksek olmasıdır. Çalışmayı, mesleki vatandaşlık, sosyal ilişki, başkalarına bakma, kişisel tatmin olarak değerlendiren bireylerin işe tutkunluk düzeyleri diğer gruplardan istatistiki olarak anlamlı bir şekilde farklılık göstermemektedir.

Bu çalışmada bireylerin cinsiyet, öğrenim durumu, yaş, deneyim süresi, çalıştı̆̆ 1 sektöre göre çalışma düşüncesinde istatistiki olarak anlamlı farklılıklar tespit edilmişken medeni durum, aylık kazanç ve pozisyona göre farklılıklar olmadığı görülmüştür. 


\section{M. Özdemir - A. Doğan 13/3 (2021) 2203-2222}

Çalışma düşüncesi, çalışma ile ilgili alternatif perspektiflerden hangisini benimsediğinin ifade edilmesinden öte bireylerin işe yönelik özel pratiklere dönüştürdükleri referans çerçeveleri, normlar, değer ve tutumlar yoluyla çalışmaya yönelik kavrayış ve deneyimlerini etkin bir biçimde şekillendirmektedir (Budd, 2011:4647). Araştırma bulguları Van Wingerden \& Van der Stoep (2018: 6) tarafından yapılan çalışma sonuçları ile uyumluluk göstermektedir. Buna göre bireyler için anlamlı olan çalışmanın bireylerin performanslarını, işe tutkunlukları ve güçlü yönleri aracılı̆̆ıyla olumlu bir şekilde etkilediği söylenebilir. Söz konusu bulgular 1şığında çalışma düşüncesinin fiili olarak çalışmanın doğasını şekillendirdiği söylenebilir. Örneğin çalışma başkalarına bakmak olarak nitelenirse, bakım işini yapanlar daha büyük saygı görecektir. Dolayıyla örgütlerin çalışmaya yönelik farklı yaklaşımları da insan yönetimine ilişkin uygulamalarında önemli farklılıklara neden olacaktır.

Çalışma düşüncesi, bireylerin ve toplumların çalışma koşullarını nasıl değerlendirdiği konusunda önemlidir. Eğer birey çalışmayı serbestçe mübadele edebileceği bir meta olarak değerlendiriyorsa, çalışma koşullarını beğenmediği işlerden ayrılma konusunda kendisini serbest hissedecektir ve bu görüşe sahip birey için çalışma büyük olasılıkla toplumsal bir mesele olarak görülmeyecektir. Çalışmanın bir sosyal ilişki olarak değerlendirilmesi durumunda ise çalışma koşulları işveren ve işgörenlerin gücünün bir yansıması olarak ortaya çıkar ve taraflar için bir pazarlık konusu haline dönüşür (Budd, 2011: 46-47).

Çalışma, sadece her birimizin geçimini sağlama yolu değildir, içinde yaşadığımız toplumu oluşturmanın ve bizi biz yapmanın temel yoludur. Çalışma bir insan etkinliği olarak bize verilmiş olana hakim olma ve onu dönüştürme, bu nedenle kendimizi yaratmanın temel yollarından biridir (Fraser, 1969:7). Bu noktada bu çalışma sonuçları bireylerin yaşama ve işe yönelik yeni ve farklı anlamlar geliştirmelerinde, iş tatmini, işyaşam doyumunun artırılması (Alarcon \& Edwards, 2011:297) gibi bireysel faydaların sağlanması amacıyla örgüt yöneticileri tarafından değerlendirilebilir. Aynı zamanda işe tutkunluk ile motivasyon, örgütsel bağlılık, örgütsel vatandaşlık davranışları (Bakker \& Albrecht, 2018:8) arasındaki ilişkiler göz önünde bulundurulduğunda bu çalışmanın sonuçları örgütsel gelişim çalışmalarında kullanılabilir.

Bu çalışmada kamu ve özel sektörde çalışan bireylerin çalışmaya bakışları ve işe tutkunluk düzeyleri incelenmiştir. Bundan sonraki çalışmalarda belli bir ücret karşılığında bir işverene bağlı olarak çalışmamakla birlikte girişimcilik, esnaflık gibi faaliyetlerde bulunarak gelir elde eden bireylerin çalışma düşünceleri ve işe tutkunluk düzeyleri incelenerek söz konusu faktörler arasında farklılık olup olmadığı incelenebilir. Ayrıca çalışma düşüncesi ile çalışan performansı, örgütsel bağlılık ve iş tatmini gibi örgütsel davranışlarla ilişkisinin incelenmesi çalışma düşüncesinin etkisinin belirlenmesi açısından önemli katkılar sağlayabilir.

Bireyler günlük yaşamlarında çalışma hakkında düşünürken zorluk, korku, tatmin veya pek çok farklı duygu yaşayabilir. Ancak çalışma bireylerin yaşantısında bir iki kelime ile kavramlaştırılamayacak kadar dinamik ve karmaşıktır. Çalışmanın çeşitli kavramlaştırmalarının tamamlayıcı olduğu analizler geliştirilerek, çalışmanın gerçek genişliği ve derin önemini yansıtan bakış açıları oluşturulmalıdır (Budd, 2013: 65). Bu araştırmada bireylerin çalışma düşüncelerini tespit etmek için kullanılan 10 tanımın yeterli olmaması durumunda diğer seçeneği de ölçeğe dahil edilmiştir. 584 katılımcıdan sadece 21'i diğer seçeneğini işaretlemiştir. Buradan hareketle çalışma düşüncesine ilişkin ölçekte kullanılan tanımlamaların katılımcıların büyük bir bölümünün düşüncesine karşılık geldiği söylenebilir.

Çalışma düşüncesinde diğer seçeneğini seçen 21 katılımcının yapmış oldukları açıklamalar incelendiğinde bir kısmının aslında ölçekte yer alan ifadelerle çok uyumlu olduğu (örneğin, "Çalı̧̧ma zenginlerin daha fazla kazanmaları için fakirlerin yaptığı modern köleliktir.", "Çalışma özgürlüktür kimseye muhtaç olmamaktır") görülmüştür. 21 katılımcının verdiği cevapların büyük kısmının birden fazla seçeneği içerecek şekilde yazıldığı, ölçekte yer almayan bir kavramsallaştırmaya atıfta bulunmadığı görülmüştür. Bu noktada bundan sonraki araştırmalarda bireylerin çalışma düşüncesinin tespit edilmesinde bu ölçeğin kullanmasının uygun olacağı ancak ölçeğin uygulanmasında katılımcıların birden fazla seçeneği seçmesi veya sıralama yapması ya da her bir çalışma tanımına ilişkin likert tipi değerlendirme yapması istenilebilir. Böylece bireylerin çalışma düşüncelerine yönelik olarak korelasyon, regresyon analizleri gibi istatistiki analizler yapmak mümkün olacağından, çalışma düşüncesinin önemi ve sonuçlarına ilişkin daha derinlikli bilgiler elde edilebilir. 


\section{Kaynakça}

Adler, A. (2002). Sosyal Duygunun Gelişiminde Bireysel Psikoloji. (H. Özgü, Çev.) İstanbul: Hayat Yayıncllık.

Alarcon, G. M., \& Edwards, J. M. (2011). The Relationship of Engagement, Job Satisfaction and Turnover Intentions. Stress and Health, 294-298.

Ardıç, K., \& Polatçı, S. (2009, Ocak- Haziran). Tükenmişlik Sendromu ve Madalyonun Öbür Yüzü: İşle Bütünleşme. Erciyes Üniversitesi İktisadi ve İdari Bilimler Fakültesi Dergisi(32), 21-46.

Arendt, H. (1994). İnsanlık Durumu. (B. S. Şener, Çev.) İstanbul: İletişim.

Aristoteles. (2018). Politika. (Ö. Orhan, Çev.) İstanbul: Pinhan Yayıncılık.

Aronson, E., Wilson, T. D., \& Akert, R. M. (2012). Sosyal Psikoloji. (O. Gündüz, Çev.) İstanbul: Kaknüs.

Bailey, C., \& Madden, A. (2015). Time Reclaimed: Temporality and the Experience of Meaningful Work. Work, Employment and Society, 1-16. doi:10.1177/0950017015604100

Bailey, C., \& Madden, A. (2019). We're Not Scum, We're Human": Agential Responses in The Face of Meaningless Work. Scandinavian Journal of Management, 35, 1-11. doi:10.1016/j.scaman.2019.101064

Bailey, C., Yeoman, R., Madden, A., Thompson, M., \& Kerridge, G. (2018). A Review of the Empirical Literature on Meaningful Work: Progress and Research Agenda. Human Resource Development Review, 1-31. doi:10.1177/1534484318804653

Bakker, A. B., \& Albrecht, S. (2018). Work Engagement: Current Trends. Career Development International, 4-11.

Bostancı, H., \& Ekiyor, A. (2015). Çalışanların Işe Adanmasının Örgüt Içi Girişimciliğe Etkisinin Incelenmesi: Sağlık Sektöründe Bir Uygulama. Uluslararası Sağ̆lı Yönetimi ve Stratejileri Araştırma Dergisi, 1(1), 3751.

Budd, J. W. (2011). Çalışma Düşüncesi. (F. Man, Çev.) İstanbul: Ayrıntı.

Budd, J. W. (2016). The Thought of Work in Employment Relations. Employ Respons Rights J, 25, 61-65. doi:10.1007/s10672-013-9212-3

Demirbaş, H. T. (2008). İş Özellikleri Algısının İş Bütünleşmesi Üzerindeki Etkisi. Yayımlanmamış Yüksek Lisans Tezi, İstanbul Üniversitesi, Sosyal Bilimler Enstitüsü.

Eryılmaz, A., \& Doğan, T. (2012). İş Yaşamında Öznel İyi Oluş: Utrecht İşe Bağlı̆ık Ölçeğinin Psikometrik Niteliklerinin İncelenmesi. Klinik Psikiyatri, 15, 49-55.

Fraser, R. (1969). Work: Twenty Personal Accounts. London: New Left Review.

George, D., \& Mallery, P. (2016). IBM SPSS Statistics 23 Step by Step A Simple Guide and Reference. New York: Routledge.

Harter, J. K., \& Hayes, T. L. (2002). Business-unit-level relationship between employee satisfaction, employee engagement, and business outcomes: a meta-analysis. Journal of Applied Psychology(87), 268-279.

Imperatori, B. (2017). Engagement and Disengagement at Work. Milan: Sringer.

Jung, C. G. (1999). Keşfedilmemiş Benlik. (C. E. Sılay, Çev.) İstanbul: İlhan Yayınevi \& Danışmanlık.

Kağıtçıbaşı, Ç. (1999). Yeni İnsan ve İnsanlar. İstanbul: Evrim Yayınevi.

Kahn, W. A. (1990). Psychological Conditions of Personal Engagement and Disengagement at Work. The Academy of Management Journal, 33(4), 692-724.

Laschinger, H., \& Finegan, J. (2005). Empowering nurses for engagement and health in hospital settings. Journal of Nursing Administration, 439-449.

Macey, W. H., \& Schneider, B. (2008). The Meaning of Employee Engagement. Industrial and Organizational Psychology, 1, 3-30.

Mauno, S., Kinnunen, U., Mäkikangas, A., \& Feldt, T. (2010). Job Demands And Resources As Antecedents Of Work Engagement: A Qualitative Review And Directions For Future Research. S. L. Albrecht içinde, Handbook Of Employee Engagement Perspectives, Issues, Research and Practice (s. 111-128). Glos: Edward Elgar.

Nizami, N., \& Prasad, N. (2017). Decent Work: Concept, Theory and Measurement. Singapur: Palgrave Macmillan. 
M. Özdemir - A. Doğan 13/3 (2021) 2203-2222

Oliveira, A. R. (2014). A History of the Work Concept. Cassino: Springer.

Özkalp, E., \& Meydan, B. (2015). Schaufeli ve Bakker Tarafından Geliştirilmiş Olan İşe Angaje Olma Ölçeğinin Türkçede Güvenilirlik ve Geçerliliğinin Analizi. "İşGüç" Endüstri İlişkileri ve İnsan Kaynakları Dergisi, 17(3), 4-19.

Prost, A. (2010). Emek. P. Aries, \& G. Duby içinde, Özel Hayatın Tarihi (Ş. Aktaş, Çev., s. 21-62). İstanbul: Yapı Kredi Yayınları.

Riggio, R. E. (2013). Introduction to Industrial / Organizational Pcychology. New Jersey: Pearson Education, Ic.

Rothbard, N. P. (2001). Enriching or Depleting? The Dynamics of Engagement in Work and Family Roles . Administrative Science Quarterly, 655-684.

Saks, A. M. (2006). Antecedents And Consequences Of Employee Engagement. Journal of Managerial Psychology, 600-619.

Salanova, M., Agut, S., \& Peiro, J. M. (2005). Linking Organizational Resources and Work Engagement to Employee Performance and Customer Loyalty: The Mediation of Service Climate. Journal of Applied Psychology, 90(6), 1217-1227.

Saruhan, Ş. C., \& Özdemirci, A. (2016). Bilim, Felsefe ve Metodoloji. İstanbul: Beta.

Schaufeli, W. B., Bakker, A. B., \& Salanova, M. (2006, August). The Measurement of Work Engagement With a Short Questionnare. Educational and Psychological Measurement, 66(4), s. 701-716.

Schaufeli, W. B., Salanova, M., Gonzalez-Roma, V., \& Bakker, A. (2002). The Measurement of Engagement And Burnout: A Two Sample Confirmatory Factor Analytic Approach. Jorunal of Happiness Studies, 3, 7192.

Schaufeli, W., \& Bakker, A. (2004). Job demands, job resources and their relationship with burnout and engagement: a multisample. Journal of Organizational Behavior(25), 293-315.

Schaufeli, W., \& Bakker, A. (2004). Utrecht Work Engagement Scale: Preliminary Manual. Occupational Health Psychology Unit Utrecht University.

Serper, Ö. (2004). Uygulamalı İstatistik 2. Bursa: Ezgi Kitabevi.

Shirom, A. (2010). Feeling Energetic At Work: On Vigor's Antecedents. A. B. Bakker, \& M. P. Leiter içinde, Work Engament A Handbook of Essential Theory and Research (s. 69-84). East Sussex: Psychology Press.

Skousen, M. (2003). Modern İktisadın İnşası. (M. Acar, E. Erdem, \& M. Toprak, Çev.) Ankara: Liberte.

Smith, A. (2011). Milletlerin Zenginliği. (H. Derin, Çev.) İstanbul: Türkiye İşs Bankası Kültür Yayınları.

TÜIK. (2021, 02 28). https://data.tuik.gov.tr/Bulten/Index?p=Isgucu-Istatistikleri-Eylul-2020-33793 adresinden alınd1

Turgut, T. (2010). Çalışmaya Tutkunluk. G. İslamoğlu içinde, Kurumlarda İyilik de Var (s. 57-87). Ankara: Nobel Yayın Dağıtım.

Turner, P. (2020). Employee Engagement in Contemporary Organizations. Cham: Palgrave Macmillan.

Van Wingerden, J., \& Van der Stoep, J. (2018). The Motivational Potential Of Meaningful Work: Relationships With Strengths Use, Work Engagement, And Performance. PLoS ONE, 13(6), 1-11. doi:https://doi.org/10.1371/journal.pone.0197599 